\title{
Late Quaternary tectonic evolution and postseismic near surface fault displacements along the Geleen Fault (Feldbiss Fault Zone - RoerValley Rift System, the Netherlands), based on trenching
}

\author{
R.F. Houtgast ${ }^{\mathrm{a}, 1}$, R.T. van Balen ${ }^{\mathrm{a}}$, C. Kasse $^{\mathrm{a}}$, \& J. Vandenberghe ${ }^{\mathrm{a}}$ \\ a Vrije Universiteit, Faculteit der Aard- en Levens Wetenschappen, de Boelelaan 1085, \\ Amsterdam, Netherlands; e-mail: hour@geo.vu.nl \\ 1 R.F. Houtgast: corresponding author
}

Manuscript received: May 2002; accepted: January 2003

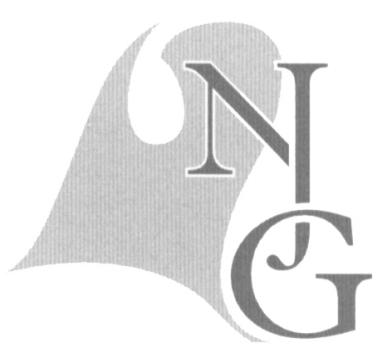

\begin{abstract}
In northwest Europe the pattern of earthquake distribution is correlated with known Quaternary faults. Excavation of fault scarps revealed that these fault zones have been active during the Late Pleistocene. In this paper we present the results of an exploratory trenching study across the Geleen Fault, part of the Feldbiss Fault Zone, the Netherlands. Middle Saalian fluvial deposits of the Meuse, overlain by local slope deposits, were excavated. The Geleen Fault has displaced the fluvial deposits by at least 5 meters. The upper layers of local slope deposits could be correlated across the fault and were all dated at approximately $15 \mathrm{ka} \mathrm{B.P.This} \mathrm{gives} \mathrm{the} \mathrm{opportunity} \mathrm{to} \mathrm{reconstruct} \mathrm{the} \mathrm{sequence} \mathrm{of} \mathrm{events} \mathrm{that} \mathrm{occurred} \mathrm{about} 15 \mathrm{ka}$ ago. Liquefactions provide evidence for an earthquake event. However, the main offset along the Geleen Fault is not stratigraphically related to the liquefactions. The liquefactions and the fault offset are stratigraphically separated by a period of erosion. We therefore propose a sequence of events starting with an earthquake accompanied by liquefaction, followed by a period of postseismic displacement with high rates compared to the long-term average. After this period normal displacement rates occurred, comparable to the long-term average. The duration of the period of high displacement rates could not be determined.
\end{abstract}

Keywords: Active tectonics, coseismic, earthquakes, Feldbiss Fault Zone, Geleen Fault, Roer Valley Graben, nonseismic, paleoseismology, postseismic

\section{Introduction and geological setting}

Identification of active faults and tectonic structures and quantification of their activity in the Late Quaternary are needed to assess the seismic hazard for northwest Europe (Camelbeeck \& Meghraoui, 1998). Ahorner (1962) proposed a pattern of earthquake distribution in northwest Europe and inferred a correlation between earthquake activity and Quaternary fault structures. In northwestern Europe many Quaternary faults have a distinctive morphological expression. In the Roer Valley Graben (Fig. 1) the fault scarps have been excavated at seven locations in order to assess paleoseismological activity (e.g. Camelbeeck \& Meghraoui, 1998; Vanneste et al. 1999; Lehmann et al. 2001). At least six surface rupturing events across the Feldbiss Fault Zone since the Late Pleistocene were recognized in a trench described by Vanneste et al. (1999). In this study we present the results of the excavation of the Geleen Fault, located at the southeastern margin of the Roer Valley Graben. In this paper the lithostratigraphy of the fault zone is presented and the activity of the Geleen Fault and its implications for morphological and sedimentary processes are reconstructed. The discussion focuses on distinguishing coseismic and postseismic displacements in the trench.

\section{RoerValley Rift System}

The Roer Valley Rift System (RVRS, part of the Lower Rhine Embayment) is located in the southern part 
of the Netherlands and adjacent parts of Germany and Belgium (Fig. 1). The last rifting episode of the RVRS started in the Late Oligocene and is still ongoing (Zijerveld et al., 1992; Geluk et al., 1994). The RVRS comprises the Venlo Block, the Peel Block, the Roer Valley Graben and the Campine and South Limburg Blocks (Fig. 1). The most active fault zones are the main border faults of the Roer Valley Graben, the Peel Boundary Fault Zone and the Feldbiss Fault Zone (e.g. Ahorner, 1962; Paulissen et al., 1985; Houtgast \& Van Balen, 2000). The Feldbiss Fault Zone is the boundary between the strongly subsiding Roer Valley Graben to the north and the uplifted South Limburg Block in the south.

The area where the Meuse River crosses the Feldbiss Fault Zone has a distinct morphology, characterized by a fluvial terrace staircase. The terrace borders are visible in the terrain as NE-SW oriented scarps (Fig. 1). Activity along the individual faults of the Feldbiss Fault Zone displaced the Meuse River terrace deposits creating NW-SE oriented fault scarps. The tectonically displaced fluvial terraces have provided the opportunity to quantify Quaternary fault activity of the individual faults of the Feldbiss Fault Zone (Hout- gast et al., 2002). In the Sittard area the Feldbiss Fault Zone comprises from south to north the Heerlerheide Fault, the Geleen Fault and the Feldbiss Fault (Fig. 1). The Feldbiss Fault Zone has an average vertical displacement rate of $40-47 \mathrm{~mm} / \mathrm{ka}$ during the Middle and Late Pleistocene. The individual faults have an average displacement rate of $10-35 \mathrm{~mm} / \mathrm{ka}$ (Houtgast et al., 2002). The displacement rate of the Feldbiss Fault decreases towards the northwest, whereas the displacement rate of the Geleen Fault increases in the same direction by about the same amount. Therefore, the Feldbiss Fault Zone is a system of overstepping normal faults (Houtgast et al., 2002).

\section{Site reconnaissance}

Detailed survey of the Feldbiss Fault Zone in the Sittard area provided several potential locations for trenching. We chose to excavate the Geleen Fault on the terrace of Middle Saalian age (Caberg 3 Terrace; Van den Berg, 1989; Felder et al., 1989). The groundwater level was below the bottom of the trench (lower than $3-4 \mathrm{~m}$ ) and a scarp of 6 meters is visible in the field. Prior to the excavation detailed coring and geo-

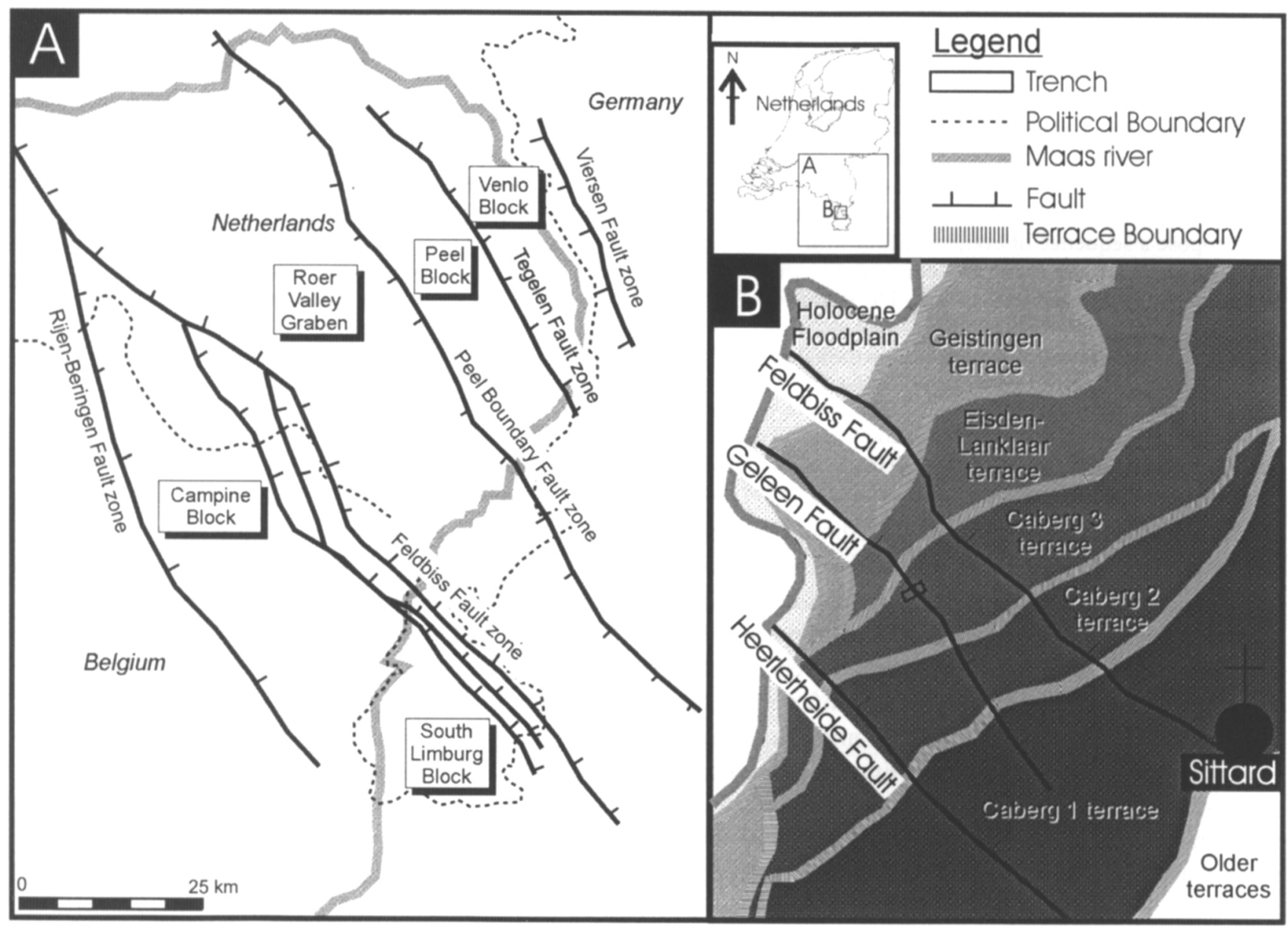

Fig. 1. Tectonic features in the southern part of the Netherlands (map A) and the configuration of faults in the Sittard area (map B). The distribution of terraces afterVan den Berg (1989) and Houtgast et al. (2002). 


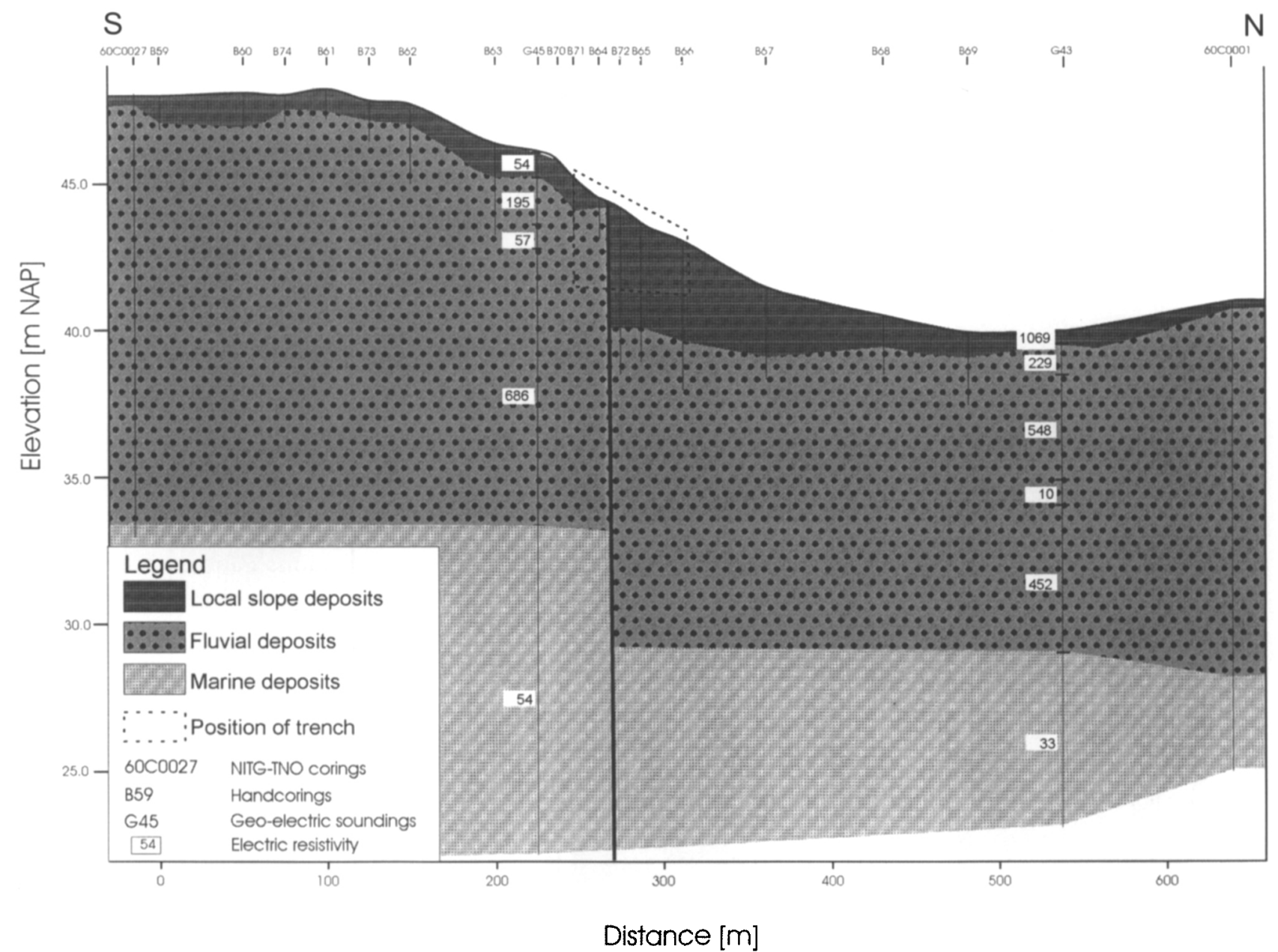

Fig. 2. Profile across the Geieen Fault, based on corings and geo-electric soundings. The marine deposits belong to the Breda Formation (Felder et al., 1989), the fluvial deposits are part of the Caberg 3 Terrace (Middle Saalian age). NAP is the Dutch ordnance system.

electric measurements were made across the scarp to locate the Geleen Fault with an accuracy of about 1 $\mathrm{m}$. The results are presented in Fig. 2. Underneath the coarse-grained terrace deposits of the Caberg 3 Terrace, fine marine sands of Miocene age are present (Felder et al., 1989). The profile indicates that the Geleen Fault displaces the terrace deposits by at least 5 to $6 \mathrm{~m}$.

In Fig. 2 the base and top of the terrace deposits are displaced by the same amount, which could imply that the fault was not active during the deposition of the Caberg 3 Terrace. However, a regional study based on more data points (Houtgast et al., 2002) shows that the Geleen Fault displaces the base of the Caberg 3 Terrace deposits by $6.4 \mathrm{~m}$ and the top by $5.8 \mathrm{~m}$. This indicates that the Geleen Fault has been active during the deposition of the Caberg 3 Terrace. On the hanging wall a 4 to 5 meter thick stack of local deposits is present, mainly composed of silts and sands.

\section{Methods}

After the exact determination of the position of the
Geleen Fault a trench, $80 \mathrm{~m}$ long and $3-4 \mathrm{~m}$ in depth, was excavated. A detailed log of the western trench wall was made. Samples were taken for grain size analysis of the different units. To get insight in the lithological composition underneath the trench, a series of hand corings was made. No organic matter was found that could be used for ${ }^{14} \mathrm{C}$ dating. Optically Stimulated Luminescence (OSL) dating was applied to obtain the age of several units.

\section{Results}

\section{Trench stratigraphy}

Table 1 summarizes the different units and subunits exposed in the trench. Fig. 3 shows a photo mosaic of the trench and an interpretative drawing of the northwestern wall of the trench is presented in Fig. 4. In general, the footwall is composed of a stack of fluvial deposits (unit A) and overlain by an alternation of fluvial sands and gravel lags (unit B), the latter indicating periods of non-deposition or erosion.

The hanging wall is mainly composed of fine- 


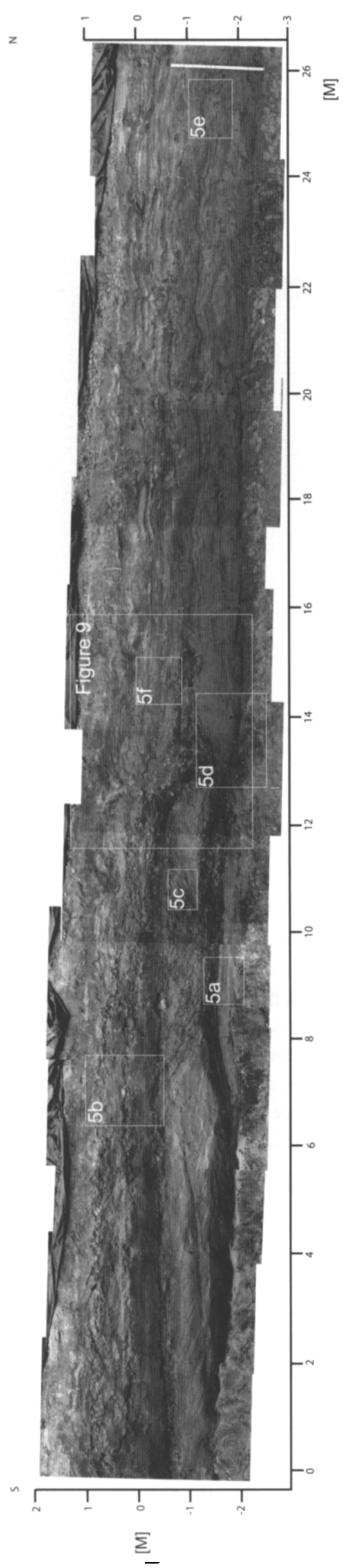

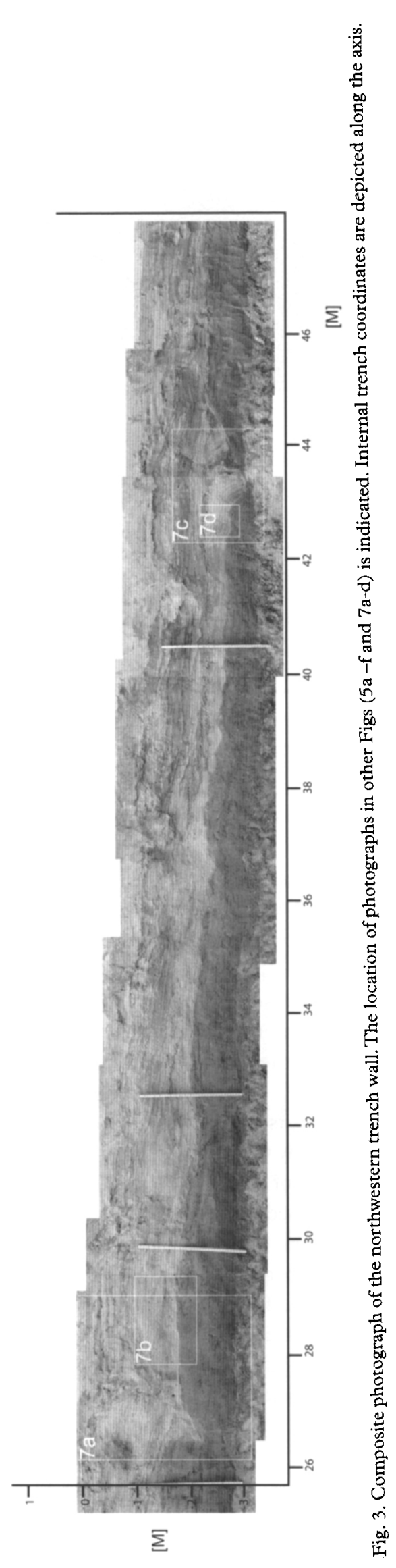

Netherlands Journal of Geosciences / Geologie en Mijnbouw 82(2) 2003 


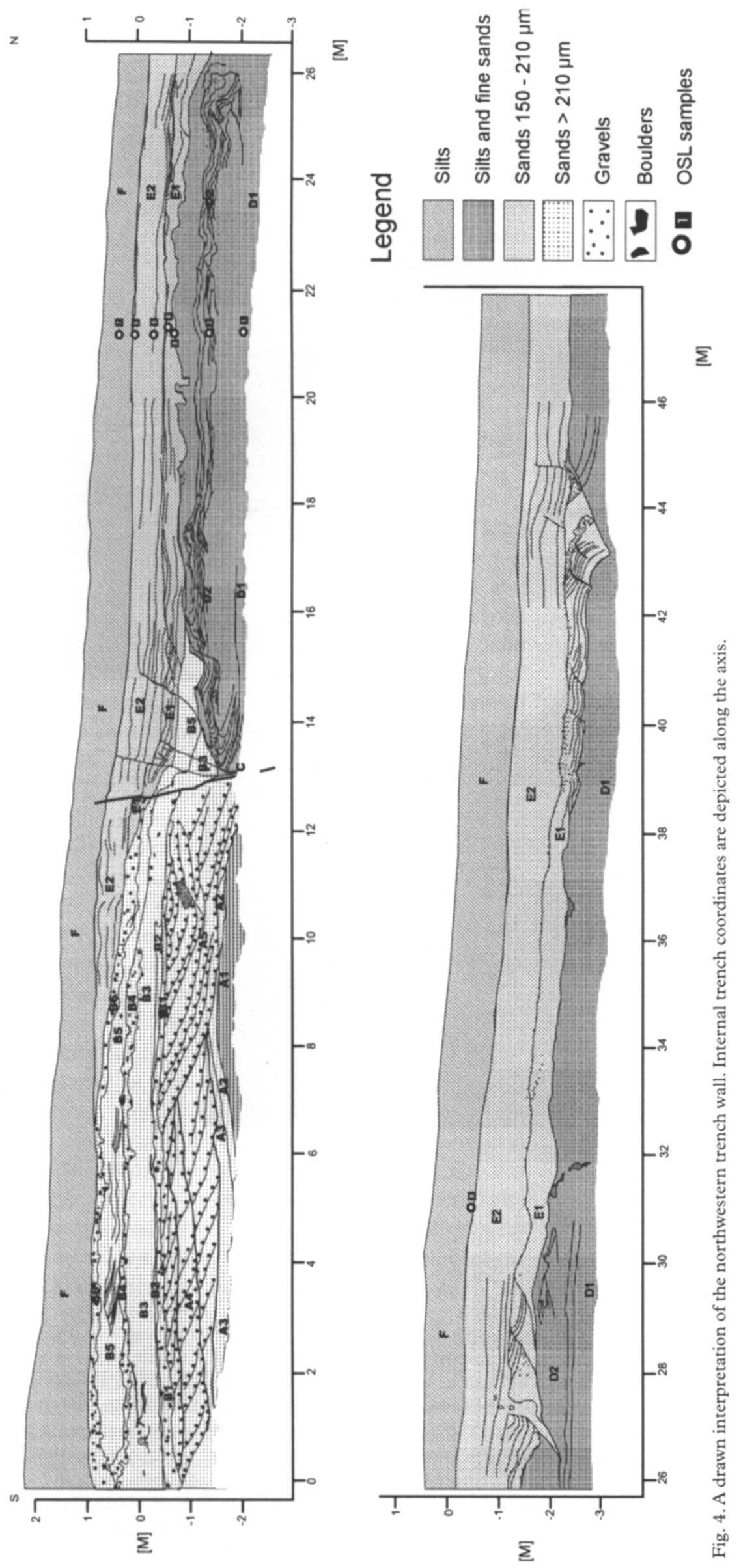


grained slope deposits (units C, D and E). On top of both the footwall and the hanging wall a $60-80 \mathrm{~cm}$ thick layer of sandy loess is present (unit F). Some specific properties or sedimentary structures of the lithostratigraphic layers are discussed below.

Unit A is a fluvial deposit, subdivided into 5 subunits (Figs. 3 and 4). Unit A1 is made up of horizontal laminae of well-sorted quartz-sands (Fig. 5a). Unit A2 is made up of silts and clay, interpreted as overbank deposits (Fig. 5a). Units A3, A4 and A5 consist of poorly sorted coarse sands and gravels with clear cross-bedding structures. These units are interpreted as channel deposits of a braided river system. Unit A5 contains a sand block, which is an indication for a frozen state during its transport (Fig. 5b).

Unit B (Fig. 5c) is subdivided into six subunits each representing distinct periods of deposition and non-deposition or erosion. Three gravel lag deposits are present (units $\mathrm{B} 1, \mathrm{~B} 4$ and $\mathrm{B} 6$ ) alternating with fluvial sandy deposits (units B3 and B5). Unit B2 is composed of a matrix of clay with coarse sands without clear sedimentary structures. Unit B7 contains
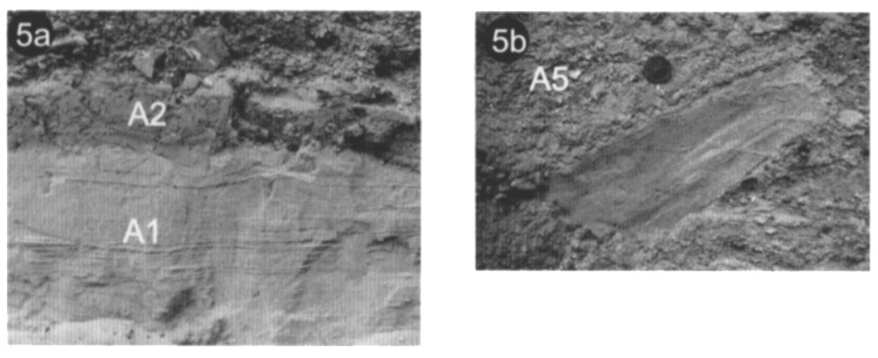

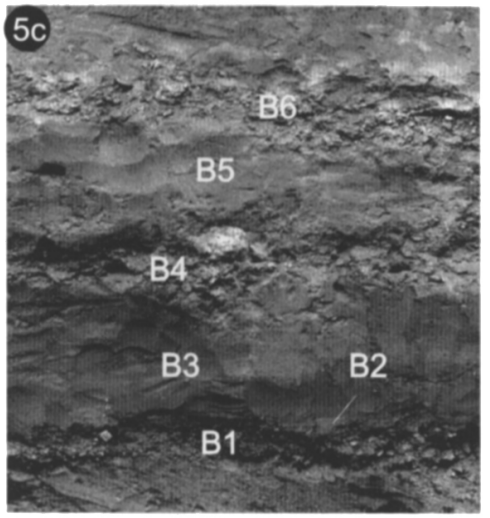

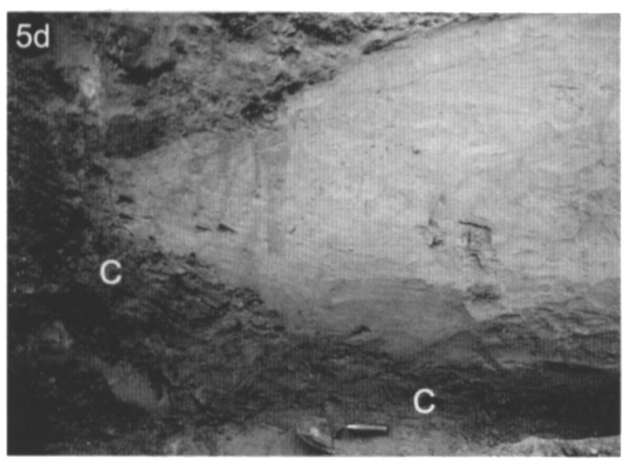

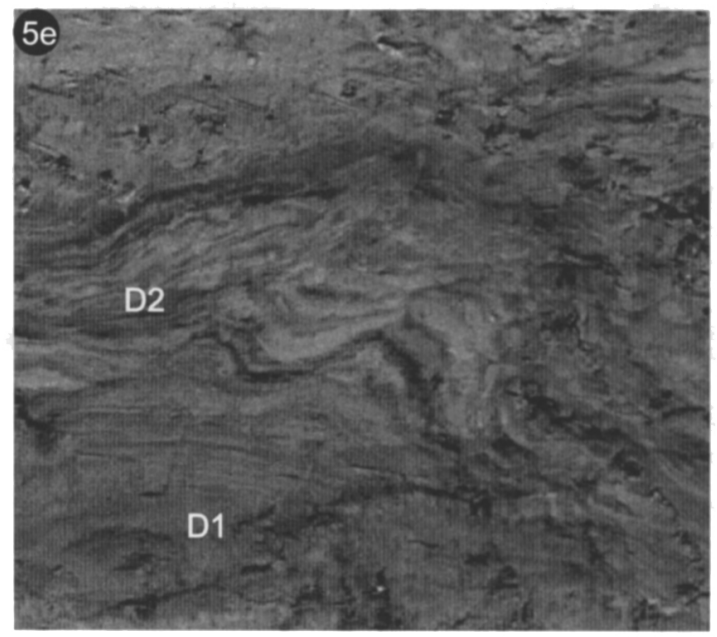

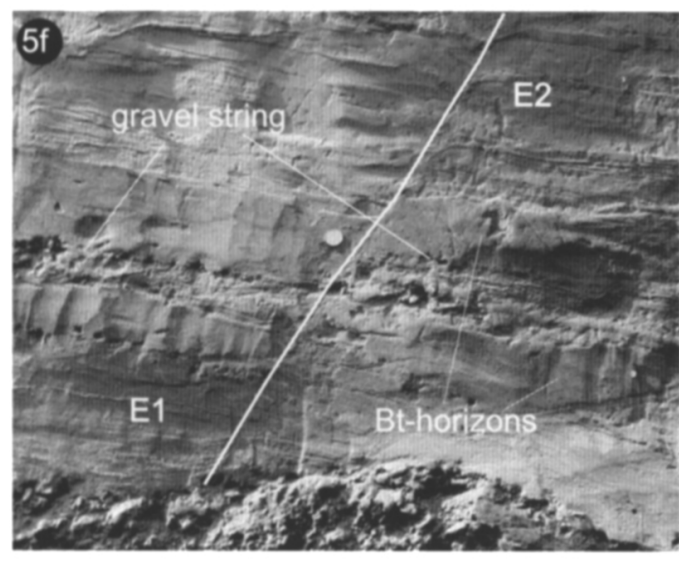

Fig. 5. Photographs of units in the trench. Location of the photographs is indicated in Fig. 3. a) Horizontally laminated sands of unit Al overlain by the silty clay layer unit A2. b) Sand block in gravel unit A5, possibly indicating a frozen state during transport. c) Overview of unit B. At the base the units B1 (gravel lag) and B2 (clay rich layer). The low energetic fluvial sands B3 and B5 are separated by gravel lag B4. The top of the unit is marked by a gravel lag deposit (unit B6). d) Colluvium, unit $\mathrm{C}$, situated near the fault, is a mixture of gravels, sands and silts. e) Deformation within unit D2 related to solifluction. f) Horizontal to low-angle laminated sands of unit $\mathrm{E}$. The Bt-horizons and the gravel string are displaced by an antithetic fault. Coin $(\sim 1.5 \mathrm{~cm}$ diameter) for scale. 


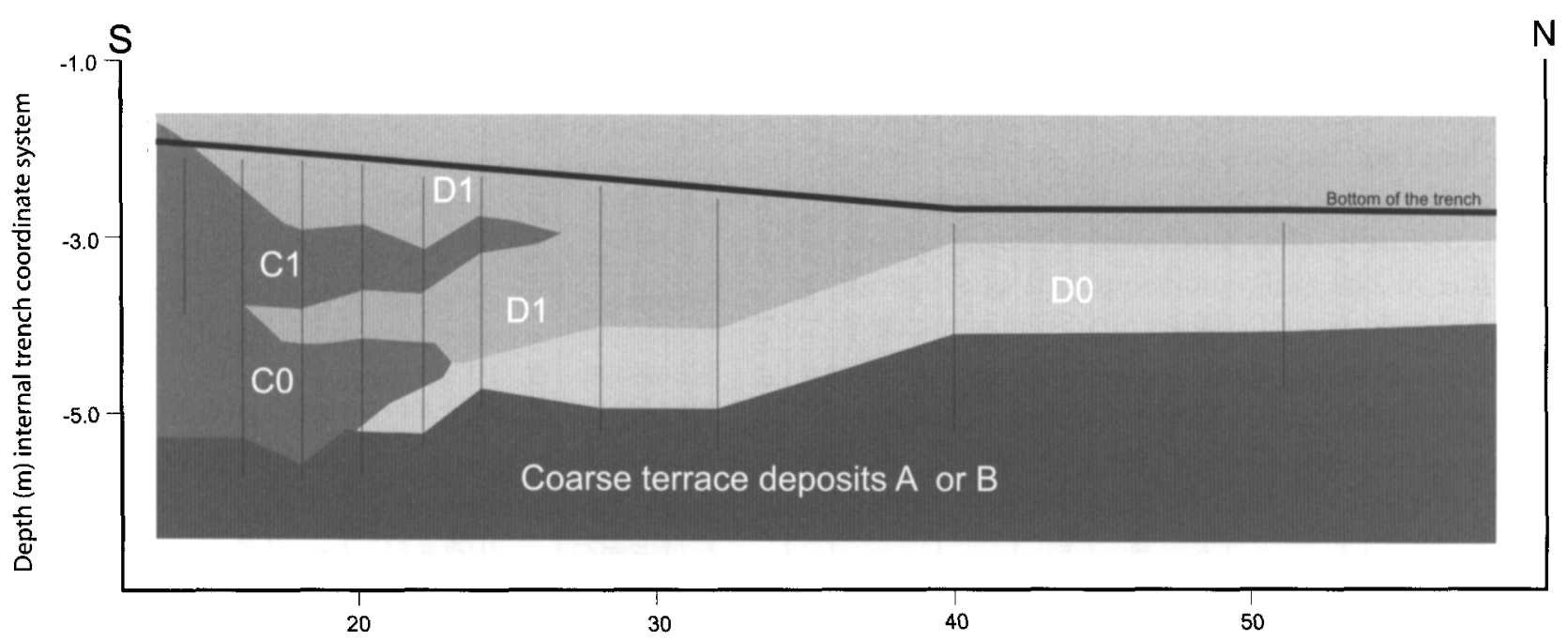

Fig. 6. Geology of the hanging wall beneath the trench, based on corings (thin vertical lines). Internal trench coordinates are depicted along the axis.

the debris at the end of the slumped part of unit B on the hanging wall.

Unit $C$ is only present on the hanging wall and most of it is situated below the bottom of the trench (Fig. 5d). This unit consists of silts, coarse sands and gravels. This unit is interpreted as colluvium. Slope processes continued to build up unit $D$, as evidenced by onlap contact between units $C$ and the lower part of unit D.

Unit $D$ is made up of thinly parallel laminated sandy silts, interpreted as a local slope wash deposit. Although both subunits were originally identical, unit D2 was subject to post-depositional deformation (Fig. 5e), while unit D1 remained undeformed.

Unit $\mathrm{E}$ is composed of horizontal to low-angle parallel lamination of sands (Fig. 5f). This is interpreted as a local slope deposit or small alluvial fans formed by sheet flow. These sediments were partly derived from local slope erosion forming gravel lag B6. The appearance of several distinct thin layers of gravels within the unit indicates periods of higher flow. The lower part of unit $\mathrm{E}(\mathrm{E} 1)$ is broken and deformed at many locations. The upper part of this unit (E2) has only been affected by small faults near the main fault.

Corings, made from the bottom of the trench, were used to study the interval between the bottom of the trench and the coarse terrace deposits (Fig. 6). It has been established that the colluvium (unit $\mathrm{C} 1$ ) has a lateral extension of about $10 \mathrm{~m}$, being $1.5-2.0 \mathrm{~m}$ thick nearby the fault and $0.5-1.0 \mathrm{~m}$ thick at a distance of $5 \mathrm{~m}$ from the fault. Underneath this colluvium a loamy layer is present, having comparable lithological characteristics as unit D1. Below unit D1 a layer containing silts, sands and gravels is present, which is possibly another colluvium layer $(\mathrm{C} 0)$. Further away from the fault a sand layer (Unit Do) is pre- sent which has a similar lithological composition as units $\mathrm{E} 1$ and $\mathrm{E} 2$. This unit appears to have a slope of $5 \%$ towards the fault between position 20 and 40 meter. This seems inconsistent with the interpretation as a slope wash deposit, but this can be explained by post-depositional tilting towards the fault. Further away from the fault (between position 40 - 60 meter) the unit is in a horizontal position.

Approximately 3 meters below the bottom of the trench coarse sands and gravels were found using hand corings. There are several indications that this is indeed the top of the terrace deposits: (i) Geo-electric measurements indicate a $10 \mathrm{~m}$ thick body of coarse deposits, starting at this level. (ii) The gravel body extends far beyond the borders of the trench and is much larger than the units $C 0$ and $C 1$. (iii) From a regional study it is known that the fault has an offset of $5.8 \mathrm{~m}$ (Houtgast et al., 2002). Based on this latter value the top of the terrace deposits should be at approximately this level. Therefore, we correlate the top of these deposits with the top of unit $A$ or the top of unit B on the footwall.

\section{Age of the units}

In Table 1 (estimated age) and Table 2 (absolute age) the ages of the units are given. Optically Stimulated Luminescence (OSL) dating was applied to determine the age of several units (see Fig. 4 for the location of the samples). In other cases the well-known regional lithostratigraphy was used.

Unit A is interpreted as channel or nearby channel deposits of a braided river system. The deposits are part of the Caberg 3 Terrace (Van den Berg, 1989; Houtgast et al., 2002). This terrace is correlated geomorphologically with the Belvédère site, near Maas- 


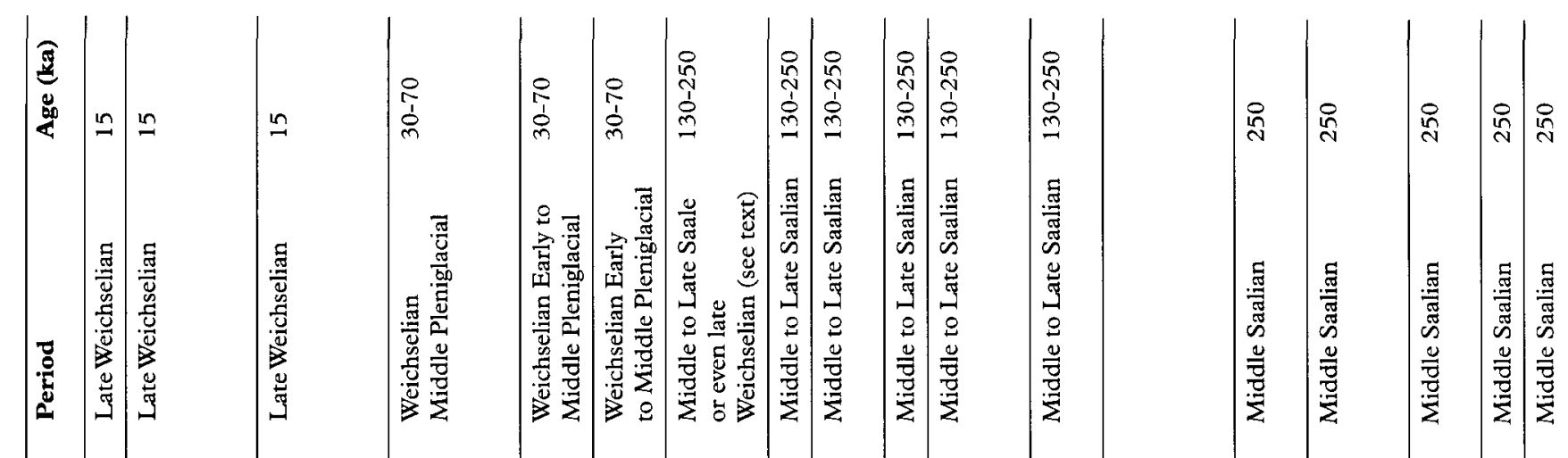

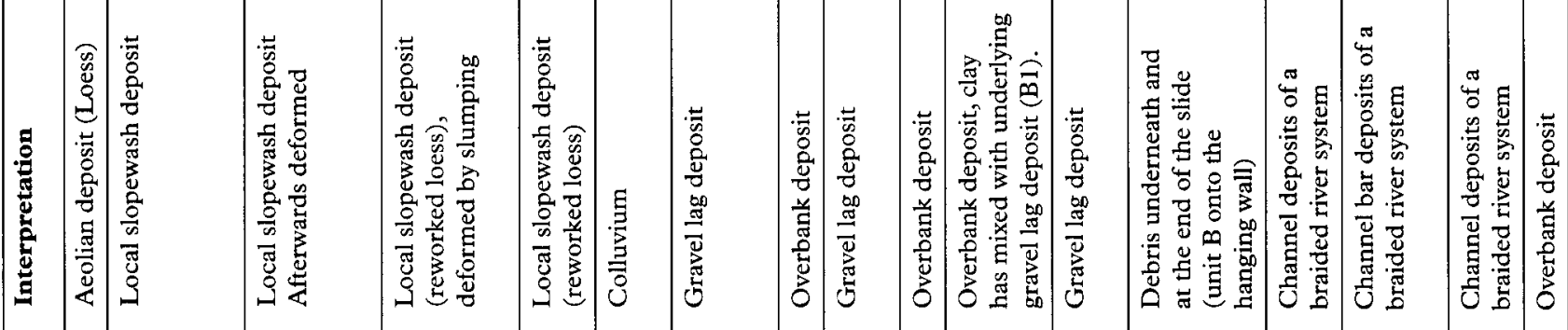

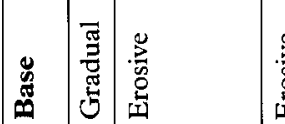

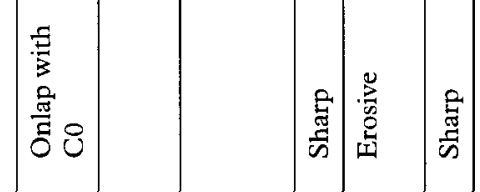

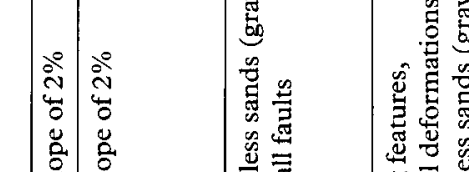

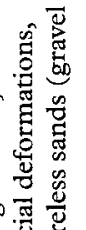

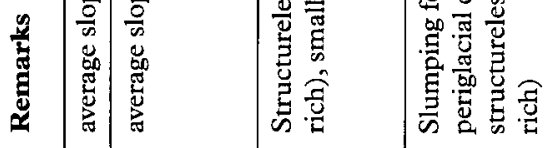

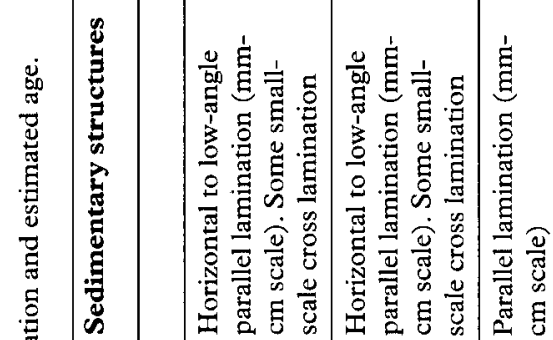

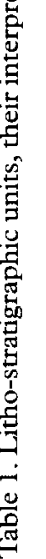

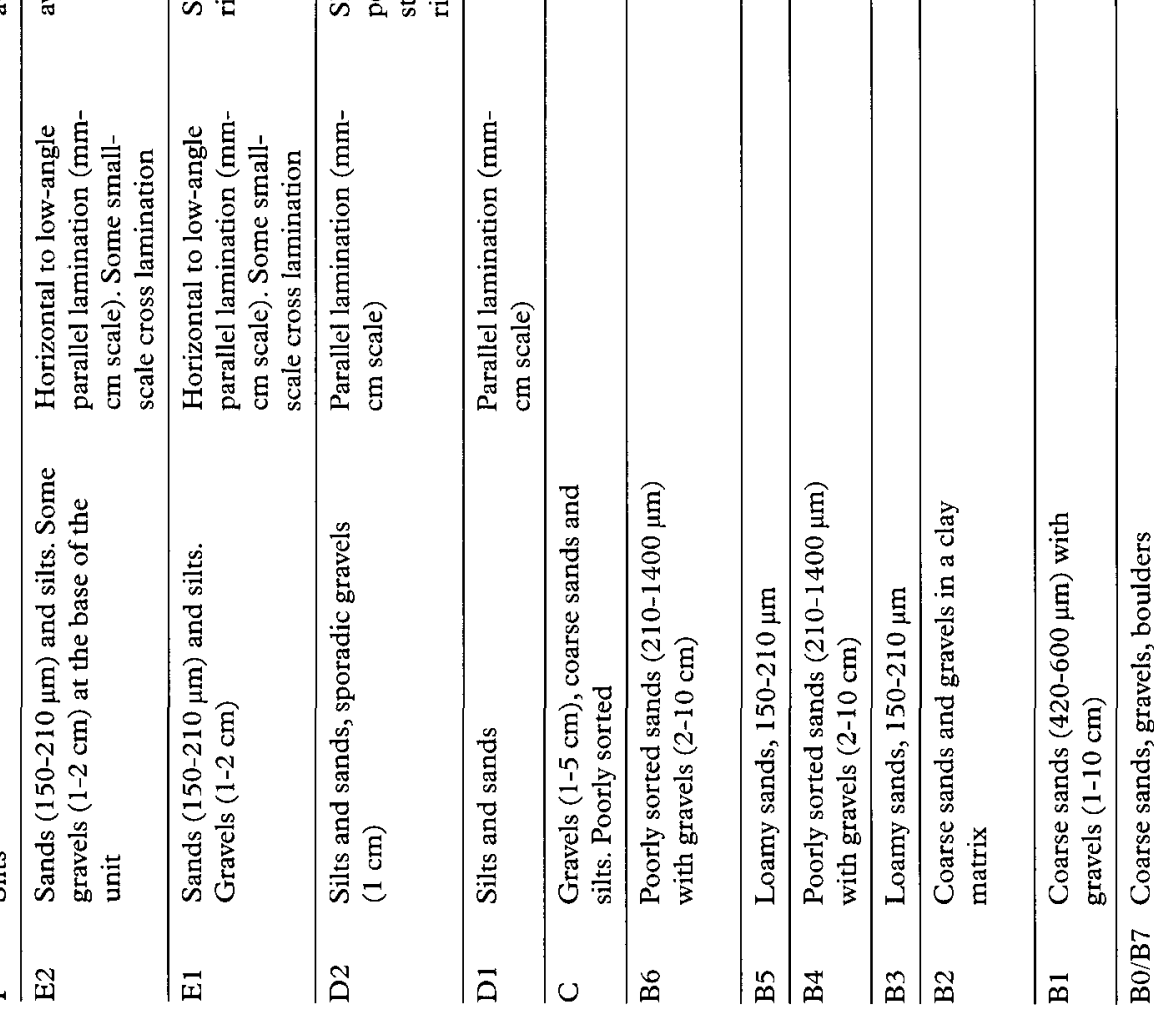

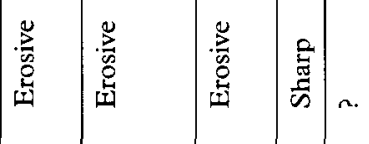

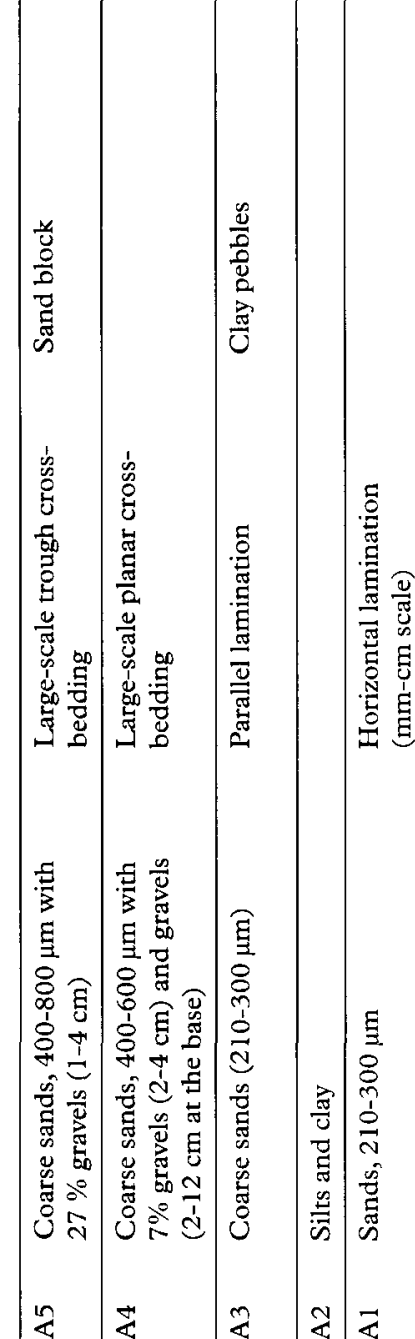


Table 2. Results of OSL measurements carried out by the Sheffield Centre for Internatonal Drylands Research (SCIDR). The single aliquot regeneration method (SAR; Murray and Wintle, 2000) was applied to quartz grains $(90-125 \mu \mathrm{m}, 90-212 \mu \mathrm{m}$ for sample $\mathrm{nr} 1)$.

\begin{tabular}{llll}
\hline $\begin{array}{l}\text { Sample } \\
\text { number }\end{array}$ & Unit & Age (ka) & $\begin{array}{l}\text { Sheffield Lab } \\
\text { number }\end{array}$ \\
\hline 1 & D1 & $36.8 \pm 2.9$ & Shfd 00016 \\
2 & D2 & $76.6 \pm 5.9$ & Shfd 00017 \\
3 & E1 & $15.2 \pm 1.1$ & Shfd 00018 \\
4 & E1 & $14.8 \pm 1.1$ & Shfd 00019 \\
5 & E2 & $14.7 \pm 1.1$ & Shfd 00020 \\
6 & E2/F & $15.0 \pm 1.1$ & Shfd 00021 \\
7 & F & $15.0 \pm 1.2$ & Shfd 00022 \\
8 & F & $15.9 \pm 1.1$ & Shfd 00023 \\
\hline
\end{tabular}

tricht (Van Kolfschoten et al., 1993). At this site the age of the Caberg 3 Terrace has been established by thermoluminescence and paleontological remains at 250 ka (Huxtable \& Aitken, 1985; Van Kolfschoten et al., 1993).

Unit B has been interpreted as (shallow) fluvial deposits (B3 and B5). The main channels of the braided river system were located outside the study area. At the trench site only occasionally sediments were deposited. During periods of erosion gravel lag deposits (B2, B4 and B6) were created. The possible ages for the lower gravel lags (B2 and B4) situated between the fluvial deposits B3 and B5 range from Middle Saalian $(250 \mathrm{ka})$ to Late Saalian $(130 \mathrm{ka})$. The upper gravel lag, unit B6, can be correlated with the formation of unit $\mathrm{E} 1$, which has been dated at $15 \mathrm{ka}$ (see below).

Although unit $B$ on the hanging wall is positioned above units $C$ and $D$, we think that this part of unit $B$ has slided from the footwall onto the hanging wall on the younger units $C$ and $D$ (see reconstruction of sedimentary and tectonic events). The deformation structures in unit $\mathrm{D}$ just below the slide suggest such a relationship.

Unit $\mathrm{C} 1$ is a colluvium deposit of silts, sands and gravels. Unit $\mathrm{D}$ has been interpreted as local slope deposits build up of reworked loess, silts and sands. Dating this unit through OSL has failed to deliver a reliable result (see Table 2). According to OSL dating unit D2 (76.6 ka) should be considerably older than the underlying unit D1 (36.8 ka). On the basis of this stratigraphic inconsistency we had to reject these OSL dates. The loess in this unit could be reworked from in-situ loess dating from the Saalian or Weichselian (Mücher, 1986). Most likely the loess originates from the Weichselian Pleniglacial, after deposition of unit B (Late Saalian) and before the deposition of loess unit F (dated by OSL, see below). The dates obtained by OSL (36.8 and $76.6 \mathrm{ka}$ ), although stratigraphically inconsistent, do support a Weichselian Pleniglacial age.

Both units $\mathrm{E}$ and $\mathrm{F}$ give OSL ages of approximately $15 \mathrm{ka}$ (Table 2), providing evidence for rapid successive deposition of both units. Unit $\mathrm{E}$ consists of two distinct layers; a lower one (E1) disturbed and deformed and the upper one (E2) still in situ (apart from some antithetic faults). This implies two phases of sedimentation without a considerable time lag (less than two thousands years).

\section{Soft-sediment deformation features}

Several soft-sediment deformation features were recognized in the exposed trench wall. These features can be divided into three categories: solifluction, slides and liquefaction features.

Unit D2 contains a structure that has the characteristics of a solifluction lobe sloping at a low angle to the north. Fig. 5e shows the end of the lobe, located between 24 and 26 meter. At some places under this structure a decollement can be recognized making the structure a detachment slide. But the absence of a clear and continuous decollement does favor an interpretation in terms of a solifluction lobe. The low angle of the slope $(2-3 \%)$ suggests water-saturated conditions, possibly related to permafrost conditions that may have been present. Permafrost conditions in the Netherlands have been described with certainty from the Weichselian Early and Late Pleniglacial (Vandenberghe, 1983). In reworked loess-like deposits, similar to unit $\mathrm{D}$, permafrost occurred also during the Weichselian Middle Pleniglacial (Huijzer, 1993). The OSL dates (samples 1 and 2, Table 2) support a Middle Pleniglacial age.

One of the most prominent features in the trench is the slide of unit $B$ from the footwall onto the hanging wall (Fig. 4, units B3 and B5 north of the fault). The slide could have used the clay rich layer (subunit B2) as a shear plane, but apart from a small deformation of subunit B2 no evidence could be found for such a decollement. The slide caused local deformation of unit D2 and some material was displaced, creating a bulge of material from unit D2 in front of the slide. Later on this material has been removed before the deposition of unit E1, as indicated by the erosional surface between units D and E. Underneath and at the end of the slide debris deposits are present, the subunits B0 and B7 (see Fig. 9).

The position of the slide next to the fault suggests a coseismic origin. However, a slide can also occur when slow postseismic creep along the fault creates a slope. We have no evidence to support either hypothesis. 

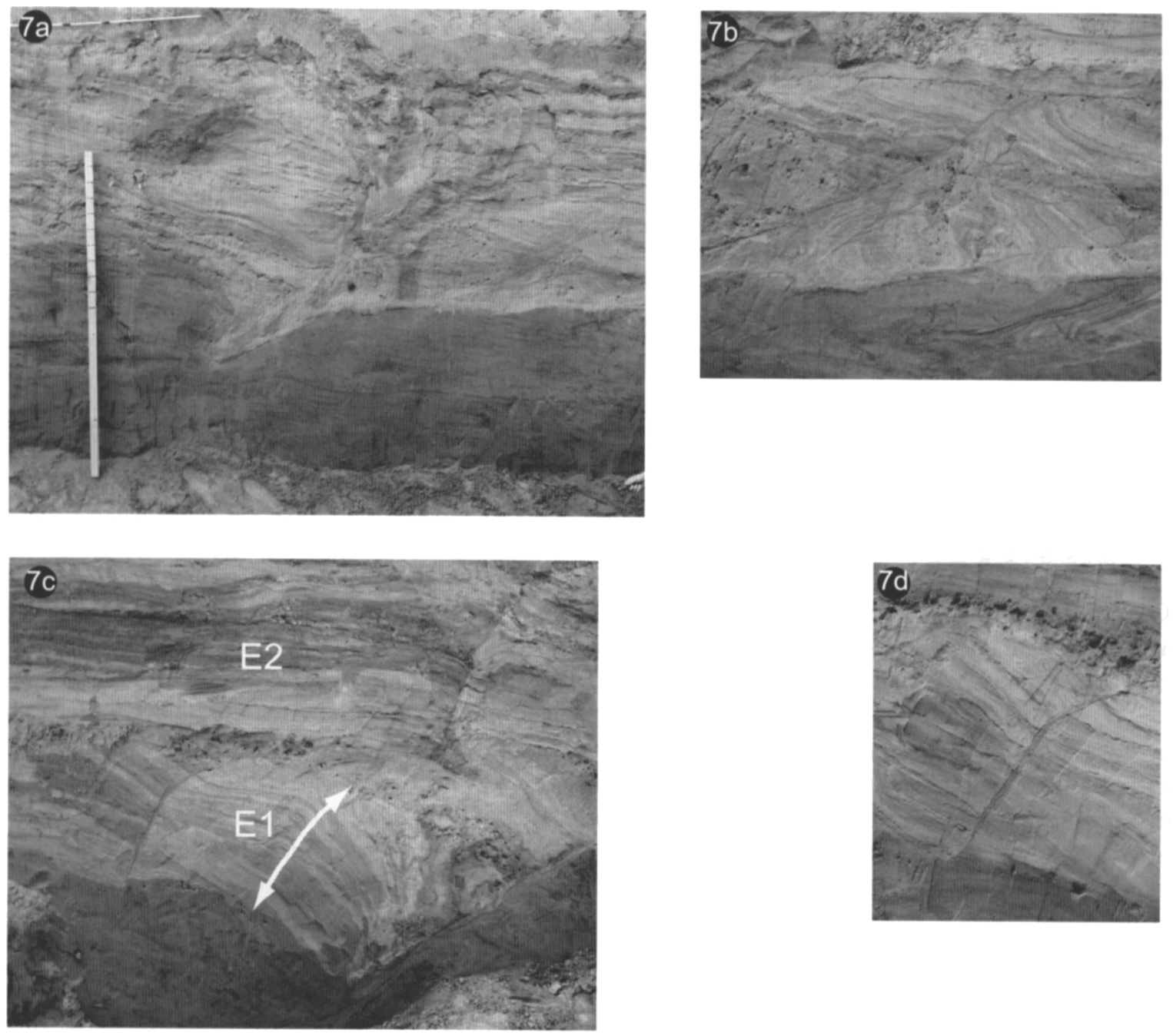

Fig. 7. Photographs of the liquefaction structures. Location of the photographs is indicated in Fig. 3. a) Liquefaction structure at $27 \mathrm{~m}$. b) Detail of the deformation of unit E1 caused by liquefaction. c) Liquefaction structure at $43 \mathrm{~m}$, the minimal thickness of unit E1 can be established at this location (see arrow). d) Clastic dike formed by liquefaction, due to the collapse of the underlying unit $\mathrm{D}$ and the consequent extension of unit E1.

Two liquefaction features have been recognized in the trench, one at $27 \mathrm{~m}$ (Figs $4 \& 7 \mathrm{a}$ ) and one at $43 \mathrm{~m}$ (Figs $4 \& 7 \mathrm{c}$ ), both affecting unit E1. At both locations, sand has been transported from below to the surface. The sands in the core of the liquefactions are structureless, which is typical for homogenization of sands under water-saturated conditions. The movement of material has caused intense deformation of unit E1 (Fig. 7b), especially at 27 and $43 \mathrm{~m}$ (Fig. 4). The deformations and appearance of cracks and clastic dykes (Fig. 7d) intensifies towards the liquefaction located at $43 \mathrm{~m}$. Movement of material from underneath the liquefaction at $43 \mathrm{~m}$ caused a partial collapse of unit D. Unit E1 was forced to extend and several cracks and clastic dykes were created (Fig. 7d).

Shaking of the ground, related to an earthquake is the most likely mechanism creating liquefaction. Shaking induces compaction and results in an instan- taneous increase of pore pressure in a sand-rich layer underneath the bottom of the trench. This caused material to be fluidized and injected into the upper layers, following zones of weakness such as ice wedges, frost cracks or small faults. The shape of the liquefaction structure at $27 \mathrm{~m}$ suggests the pre-existence of an ice-wedge cast or a large frost crack. Liquefaction during an earthquake most commonly originates at a depth ranging from a few meters to about 10 meters. A low-permeable cover (in this case unit D1) must be present to create high pore pressures. A well-sorted sand-rich deposit or a poorly sorted sandy to silty deposit are the most likely candidates to be liquefied (Obermeier, 1996). All layers below the bottom of the trench are susceptible to liquefaction using these criteria, but the most likely layer to be liquefied is the well-sorted slope wash deposit situated a few meters below the bottom of the trench (unit D0, Fig. 6). In addition, the visible part of unit D1 in the 
trench was not liquefied. Major liquefaction phenomena related to the 1992 Roermond earthquake have been reported in the nearby Roer Valley Graben (Davenport et al., 1994).

Figs $8 \mathrm{a}-8 \mathrm{c}$ show the reconstruction of events. Fig. $8 \mathrm{a}$ shows the situation before the liquefaction event. Sandy slope wash deposits of unit E1 are deposited and periglacial structures, such as frost cracks, formed by intense surface cooling, penetrate the ground. In Fig. $8 \mathrm{~b}$ the liquefaction event occurs. Fine sands from the underlying unit D0 are liquefied moving upwards along the periglacial zones of weakness. Strong deformation of unit E1 occurs and local extension of unit E1 leads to the formation of clastic dykes. After the liquefaction event a short phase of erosion, indicated by a gravel string that separates

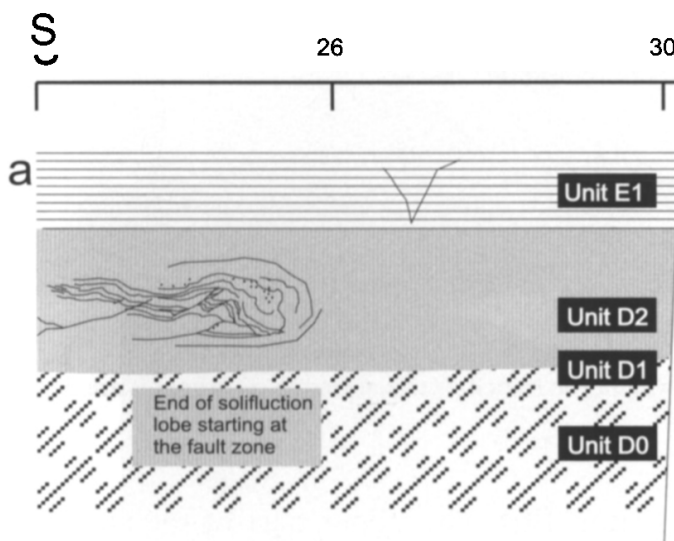

$30 \quad 38$

$\mathrm{N}$

43 $46 \mathrm{~m}$
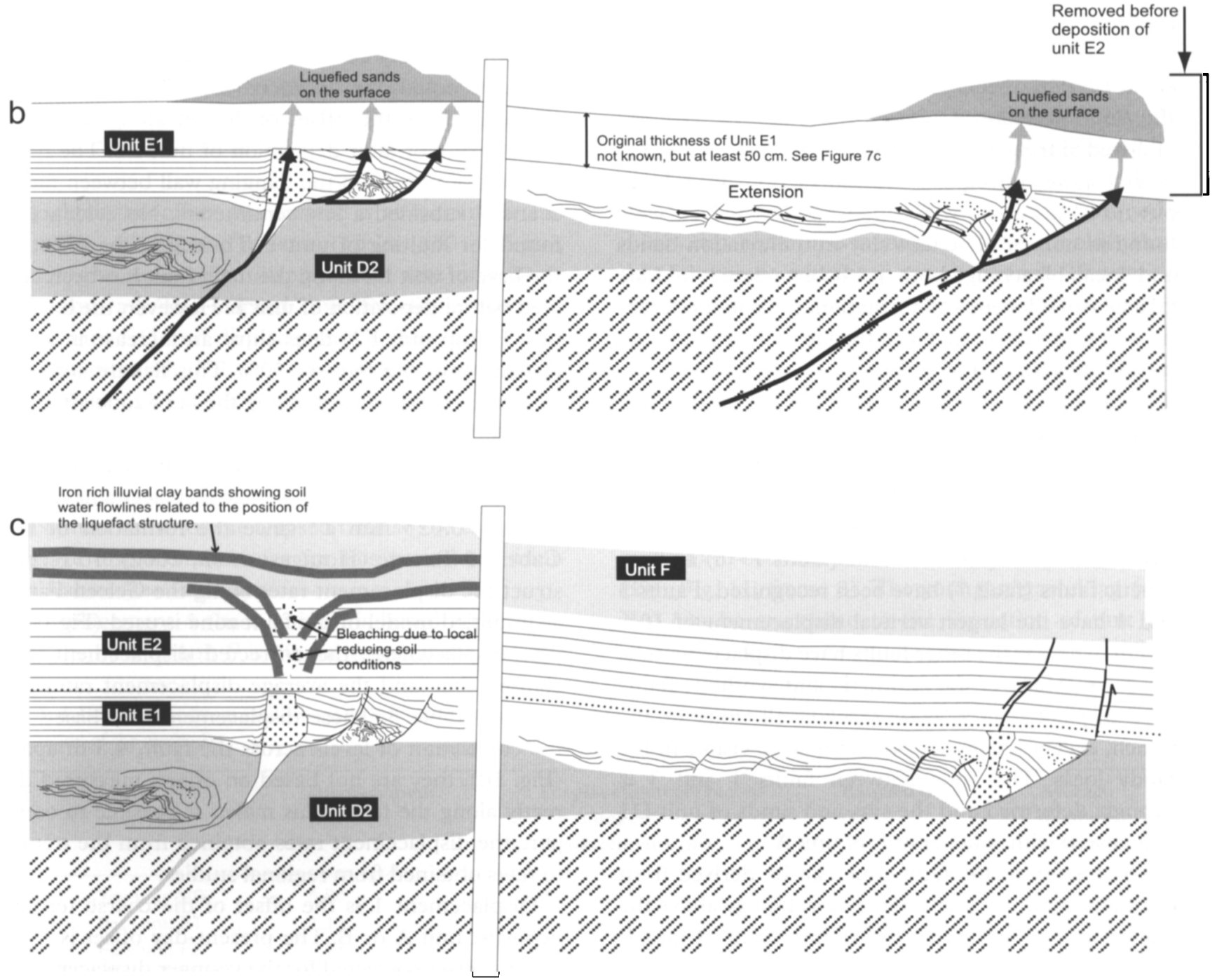

Fig. 8. A reconstruction of events related to the liquefaction features. Internal trench coordinates are depicted along the axis. 

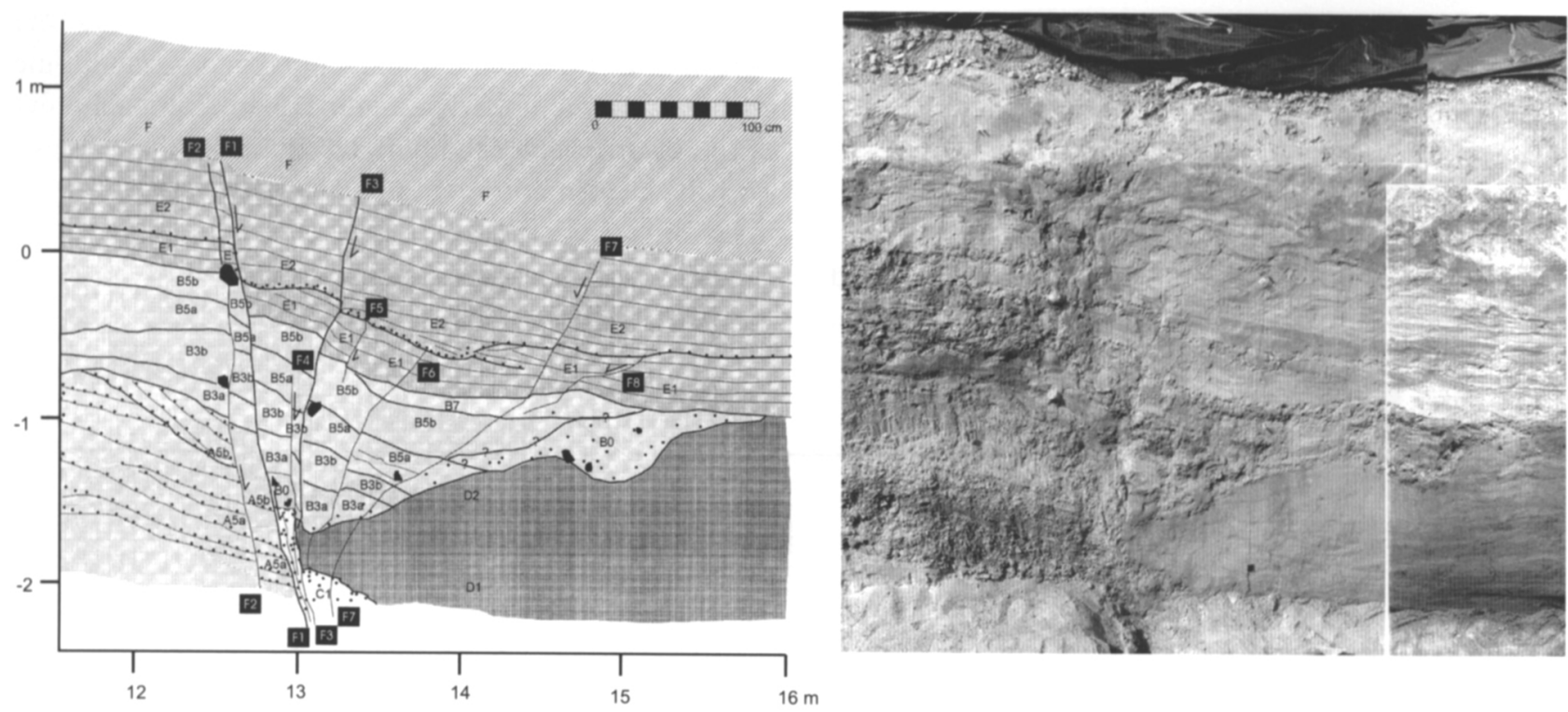

Fig. 9. Composite photograph and drawing of the Geleen Fault in the northwestern wall of the trench. Internal trench coordinates are depicted along the axis.

units $\mathrm{E} 1$ and $\mathrm{E} 2$, removed all structures and liquefaction material on the surface. The original (minimum) thickness of unit $\mathrm{E} 1$ can be established at the second liquefaction structure (at $42-44 \mathrm{~m}$ ). At least $50 \mathrm{~cm}$ of unit $\mathrm{E} 1$ has been preserved in that structure (see Fig. 7c). Therefore, at least $20 \mathrm{~cm}$ of unit E1 has been removed during that erosion phase. Unit E2 shows several small faults above the liquefaction at $42-44 \mathrm{~m}$, but no zones along which material has moved were found in unit E2. The thin clay-iron illuviation bands and local bleaching, both probably related to Late Glacial or Holocene soil formation, indicate preferential soil water flow related to the location of the liquefaction structures (Fig. 8c).

\section{Fault displacement rates}

The fault zone (Fig. 9) is a $10-20 \mathrm{~cm}$ wide zone of deformation (the area of faults 1, 2 and 3, Fig. 9 lower part). Several synthetic faults (faults $1-6$ ) and antithetic faults (fault 7) have been recognized. Faults 3 and 4 have the largest vertical displacement of $10-$ $20 \mathrm{~cm}$, whereas the other faults have displacements of $1-5 \mathrm{~cm}$. Many of the antithetic and synthetic faults have displaced or at least cracked all units in the trench, except for unit F. No faults were visible in the sandy loess. The zone between faults 1 and 3 is strongly deformed and the silts and sands of unit D1 have mixed with some gravels of unit $\mathrm{A}$.

The history of the fault zone can be derived from the main fault, $F 1$. The surface morphology above the fault zone was leveled by the sliding event of unit B onto unit D2 of the hanging wall (Fig. 9). The base of the slide on the hanging wall is sharp and underlain by debris (unit B0). The upper part of the slide was eroded before deposition of unit E1. The top of the slide (unit B5b, Fig. 9) is offset by the main fault FI by approximately $20 \mathrm{~cm}$. The displacement of the top of unit $\mathrm{B}$ equals the displacement of the base of unit E2. This dates the offset of $20 \mathrm{~cm}$ along the main fault during or after deposition of unit E2. The middle part of unit $B$ on the hanging wall between faults 3 and 7 subsided a few centimeters. No evidence is found for faulting of unit F. Therefore, the offset of the base of unit E2 along the main fault has been created before deposition of unit F. However, the base of unit F (top unit E2) does show an increase in slope just north of the fault to $30 \%$. This flexure suggests slow movements (creep) along the fault zone after deposition of units E2 and F.

A regional geomorphological study suggests that the Geleen Fault had an average displacement rate of $0.019-0.023 \mathrm{~mm} \mathrm{a}^{-1}$ since the formation of the Caberg 3 Terrace (Houtgast et al., 2002). To reconstruct the displacement rates along the Geleen Fault, a simplified model of the fault zone is used (Fig. 10). The displacement, the corrected displacement, the elapsed time and the average displacement rates are given in Table 3. These displacements are based on the correlation of levels across the fault, $4.5 \mathrm{~m}$ apart (Fig. 10), they are not based on offsets measured directly along the fault. This makes it possible to compare the displacement rates obtained from the trench to rates obtained from regional studies.

Displacement 1 is the offset of the coarse terrace deposits, unit A or B. The present-day offset is 5.80 $\mathrm{m}$. The offset corrected for the younger displacements 2,3 and 4 (Table 3 ) is $4.65 \mathrm{~m}$. The elapsed time dur- 


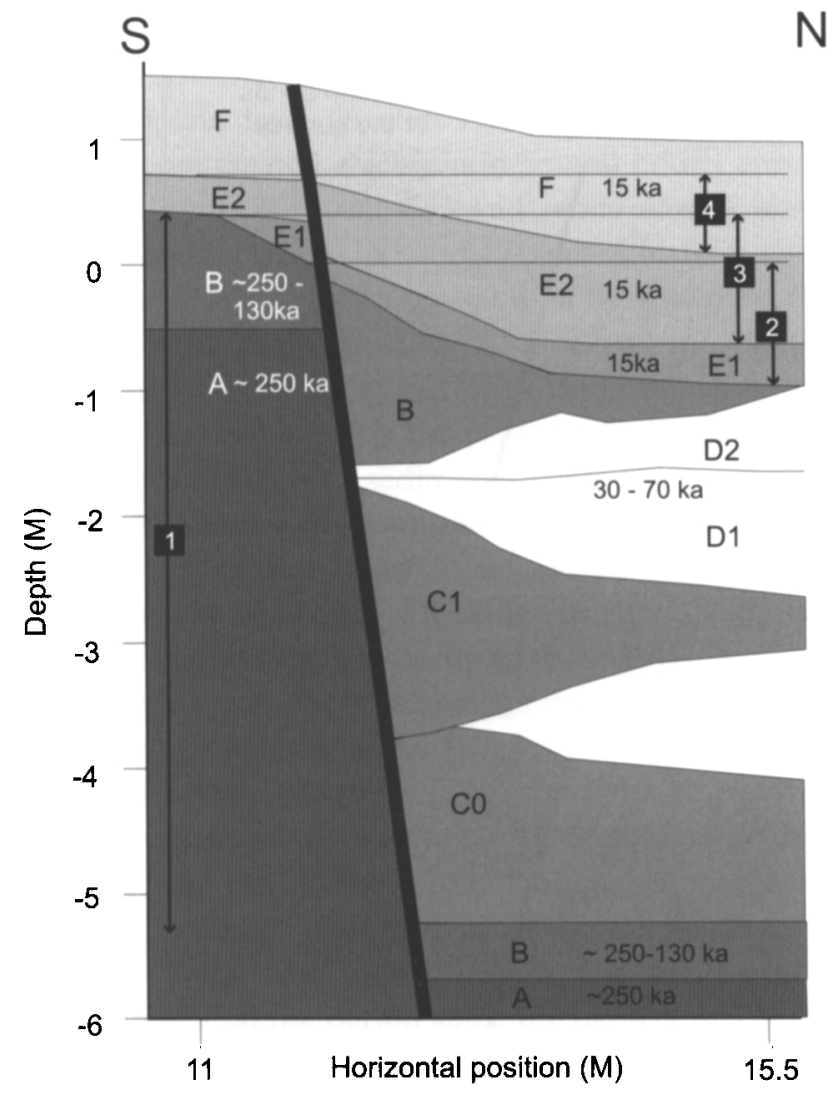

Fig. 10. The simplified model of the Geleen Fault zone, used to reconstruct fault displacement rates (see Table 3). Internal trench coordinates are depicted along the axis.

ing which this offset was created is at maximum 235 $\mathrm{ka}(250-15 \mathrm{ka})$ and at least $115 \mathrm{ka}(130-15 \mathrm{ka})$, which give an average displacement rate of 0.02 to $0.04 \mathrm{~mm} \mathrm{a}^{-1}$. The elapsed time for displacement 2 (base unit E1) and displacement 3 (base unit E2) is hard to establish. The OSL datings give an age range of $13.6 \mathrm{ka}$ (14.7 - $1.1 \mathrm{ka}$, sample 5; Table 2) to 16.3 ka $(15.2+1.1 \mathrm{ka}$, sample 3 ; Table 2$)$ for unit $\mathrm{E}$. This age range $(2.7 \mathrm{ka})$ is used to calculate the average displacement rate for both these displacements. It is the maximum value for the elapsed time so the calculated average displacement rates for this period are minimal values (see Table 3).

Displacement 4 (base unit F) is based on the fact that the base of unit $F$ is $60 \mathrm{~cm}$ lower on the hanging wall. The initial height difference of this unit during deposition is unknown, but the underlying slope wash deposit (unit E) had a slope of 2 to 3 percent. Therefore, the base of the unit was initially probably $10-$ $15 \mathrm{~cm}$ lower on the hanging wall. The large increase in gradient (from 2 to $30 \%$ ) just north of the fault (F1, Fig. 9) indicates that the Geleen Fault has been active after depositing unit $\mathrm{F}$. Therefore, the calculated displacement rate must be considered as a maximum value.

The average displacement rates for displacements 1 and 4 are of the same order of magnitude $(0.02-$ $0.04 \mathrm{~mm} \mathrm{a}^{-1}$ ). Displacements 2 and 3 have an average displacement rate at least 2 to 3 times larger, depending on the used estimation of the elapsed time (less than $2.7 \mathrm{ka}$ ). This suggests that the period around 15 $\mathrm{ka}$ is characterized by significantly larger displacement rates than the long-term average.

\section{Reconstruction of sedimentary and tectonic events}

Based on the trench logs, stratigraphy, corings, OSL dating and the regional geology we reconstructed sequential events along the Geleen Fault on the Caberg 3 Terrace (Fig. 11). The slide of unit B onto the hanging wall, which leveled the surface directly above the fault, has effectively reset the fault displacement. This divides the reconstruction in two parts. The period before the slide event is largely reconstructed from sediments exposed in the footwall as no layers older than the slide can be correlated across the fault. The period after the slide is completely represented in the trench and all layers can be correlated across the fault.

The reconstruction begins in the Middle Saalian ( $250 \mathrm{ka}$; Fig. 11, frame 1) when the Meuse River formed the Caberg 3 Terrace deposits of unit A (Van Kolfschoten et al., 1993). Towards the end of this period of gravel deposition, there were at least two periods of erosion creating gravel lag deposits (units B2 and B4) in between the fluvial deposits (units B3 and B5) (Fig. 11, frame 2). The youngest gravel lag (unit B6) can be correlated to the formation of unit E1, dated at $15 \mathrm{ka}$.

Table 3. Fault displacement rates, based on displacements of corresponding levels across the fault at a distance of $4.5 \mathrm{~m}$ apart (see text for explanation of the method).

\begin{tabular}{|c|c|c|c|c|c|}
\hline $\mathbf{N r}$ & Units & $\begin{array}{l}\text { Displacement } \\
\text { (m) }\end{array}$ & $\begin{array}{l}\text { Displacement corrected } \\
\text { for younger } \\
\text { displacements }(\mathrm{m})\end{array}$ & $\begin{array}{l}\text { Elapsed time } \\
\text { (ka) }\end{array}$ & $\begin{array}{l}\text { Average } \\
\text { displacement } \\
\text { rate }(\mathrm{mm} / \mathbf{a})\end{array}$ \\
\hline 1 & Top unit A/B & 5.80 & 4.65 & $\approx 235-115$ & $0.02-0.04$ \\
\hline 2 & Base unit E1 & 1.15 & 0.20 & $<2.7$ & $>0.07$ \\
\hline 3 & Base unit $\mathrm{E} 2$ & 0.95 & 0.35 & $<2.7$ & $>0.13$ \\
\hline 4 & Base unit $F$ & 0.60 & 0.60 & $\approx 15$ & 0.04 \\
\hline
\end{tabular}




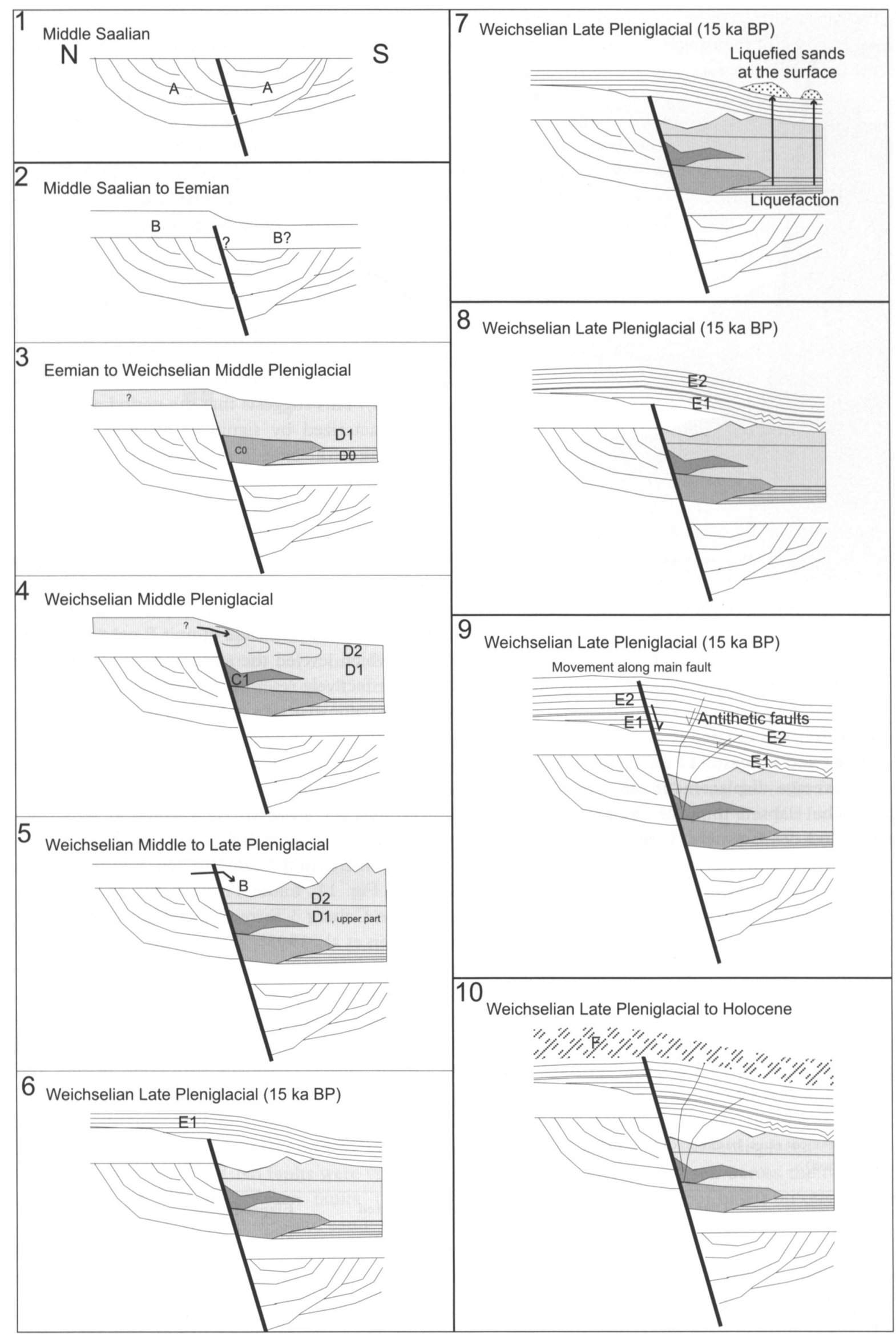

Fig. 11. Reconstruction of the sequence of events along the Geleen Fault from the Middle Saalian to the Holocene. 
During the Weichselian, the Meuse River was situated ca. 3-4 km west of the trench location at a lower floodplain level (Eisden Lanklaar Terrace). Fault movements created a scarp and several poorly sorted colluvial units ( $\mathrm{C} 0$ and $\mathrm{C} 1$ ) and sandy to silty slope wash deposits (units DO and D1) were formed (Fig. 11 , frames $3 \& 4$ ). An OSL dating of $36.8 \mathrm{ka}$ from the top of unit D1 indicates a Weichselian Middle Pleniglacial age. Associated with the scarp development and possibly related to permafrost conditions in the fine-grained silty sediments (unit D), a solifluction lobe developed on the northward sloping hanging wall (Fig. 11, frame 4). At some time during the Weichselian Middle to Late Pleniglacial a slide occurred of unit $\mathrm{B}$ from the footwall onto the hanging wall (Fig. 11, frame 5). This happened before the deposition of unit E1, which eroded the upper part of the slide.

The upper units (E1, E2 and F) were all deposited during the Weichselian Late Pleniglacial (approximately $15 \mathrm{ka}$ as established by OSL dating) (Fig. 11, frames $6-10$ ). Analysis of the average displacement rates show that the period since the deposition of unit $\mathrm{E}$ can be subdivided into two parts. The displacement rate in the period starting with the formation of unit E1 and ending before the formation of unit $F$ is at least two to three times larger than the average rate since the Middle Saalian. The displacement rate in the period after the formation of unit $F$ is comparable to the long-term average (see Table 3).

After formation of the sandy slope wash deposit of unit $\mathrm{E} 1$ the ground was shaken by at least one earthquake and caused liquefaction along pre-existing zones of weakness at two locations in the trench (Fig. 11 , frame 7). Because the base of unit E2 truncates the liquefaction features, the liquefaction must have occurred before the deposition of unit E2 (see Figs $8 \mathrm{a}, 8 \mathrm{~b}$ and $8 \mathrm{c}$ ). No fault displacement directly along the fault can be related to the liquefaction event, because the base of unit E1 has been displaced as much as the base of unit E2 (see Fig. 9). Erosion preceding deposition of unit E2 removed the upper part of unit $\mathrm{E} 1$, and at least $20 \mathrm{~cm}$ of material was eroded (Fig. 11 , frame 8). Stratigraphically, this erosion phase separates the liquefaction event in time from faulting events that occurred after the deposition of unit E2. During or after deposition of unit E2, the offset of 20 $\mathrm{cm}$ along the main fault (fault 1, Fig. 9) was created (Fig. 11, frame 9), probably before the formation of unit F. Also, the area between the faults 3 and 7 (see Fig. 9) moved approximately $5-10 \mathrm{~cm}$. In the vicinity of the liquefaction structure at 42-44 $\mathrm{m}$ unit E2 was slightly (a few centimeters) displaced by small faults. After the formation of unit $\mathrm{F}$ during the Late Weichselian (Fig. 11, frame 10) no deposition took place at the location. The base of unit $F$ is approximately 60 $\mathrm{cm}$ lower on the hanging wall, but no evidence for faulting was found in the upper part of unit E2 and unit $\mathrm{F}$. This can be explained by flexure across the fault, accompanied by a displacement rate comparable to the long-term average. Alternatively, a fault may be present in the upper layers (unit F), but the homogeneous nature of the loess of unit $F$ prevented its discovery.

\section{Discussion}

\section{Seismic and nonseismic fault movements}

In general, fault displacements deduced from terrain forms and/or the sedimentary record can be the result of either earthquake events or slow creeping move-

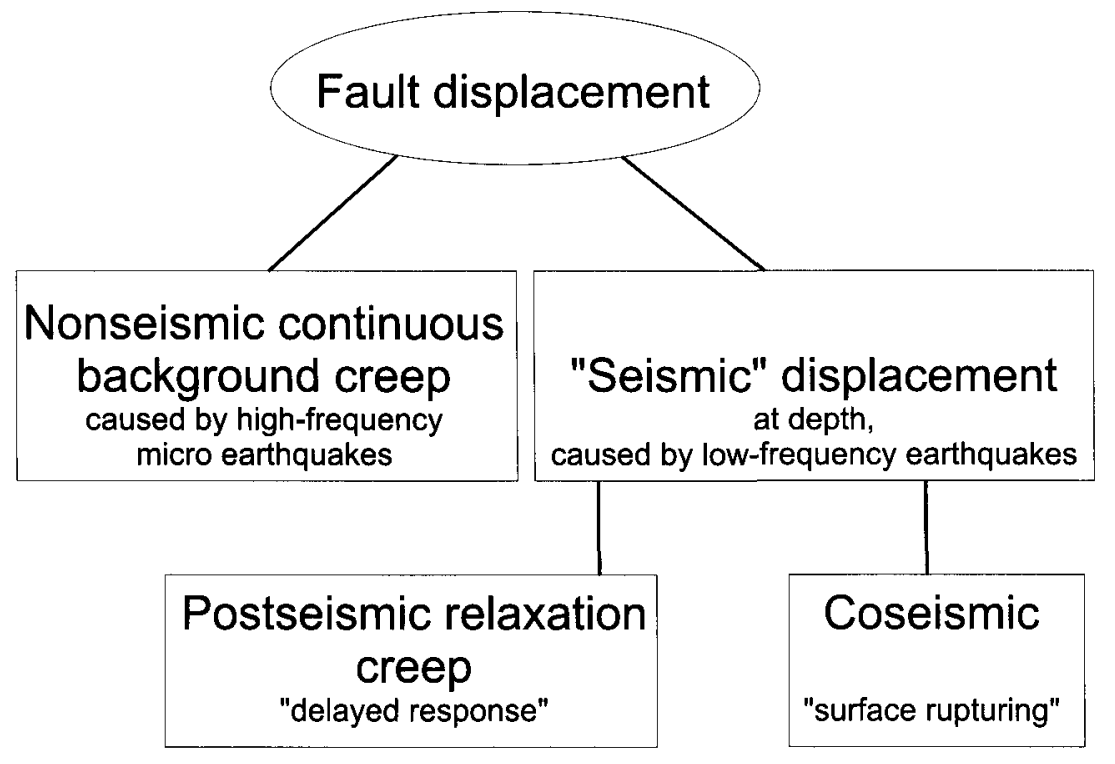

Fig. 12. Diagram of the different types of displacement, discriminating between seismological and paleo-seismological definitions for coseismic slip. 
ments. The first type of movement is termed seismic, the latter nonseismic (see Fig. 12). The nonseismic fault movements are caused by small high frequent undetectable micro earthquakes (Cowan, 1999), resulting in continuous creep. In some cases, an earthquake event may lead to surface rupturing if the combination of magnitude and the focal depth is sufficient, these abrupt movements are called coseismic. The period of vertical movements at the surface as a delayed response to that earthquake is termed postseismic relaxation creep. It is important to note that post-seismic relaxation creep can also occur without a preceding coseismic surface rupturing when the earthquake occurred at large depth and the magnitude of the earthquake was not large enough to cause surface rupturing. For example, in the Lower Rhine Embayment, most historical earthquakes occur at 10 - $20 \mathrm{~km}$ depth (Plenefisch \& Bonjer, 1997) and are not associated with surface rupturing. The largest earthquake in historical times, the Roermond earthquake $\left(M_{w} 5.4, M_{1} 5.8\right)$ at the Peel Boundary Fault (Fig. 1), had a focal depth of $17 \mathrm{~km}$ (Camelbeeck et al., 1994), and did not cause surface rupturing. However, this earthquake did cause near-surface fluidizations, creating clastic dykes and sand volcanoes (Davenport et al., 1994). So the earthquake could only be demonstrated from preserved fluidization structures, not from co-seismic displacement (i.e. surface rupture). Vertical movements determined from leveling studies over a period of 50 years (this period does not include the Roermond earthquake of 1992) show a movement of about $10 \mathrm{~cm}$ in 20 years at one specific location over the Peel Boundary Fault (Fig. 13; Groenewoud et al., 1991). These movements are the result of either non-seismic or post-seismic displacements associated with preceding earthquake(s) at depth. We suggest that these geodetic movements are of the second type (post-seismic relaxation creep, Fig. 12), because the inferred displacement rates of $2 \mathrm{~mm} \mathrm{a}^{-1}$ are 25 times the long-term average displacement rates (in the order of $0.08 \mathrm{~mm} \mathrm{a}^{-1}$ ) derived from the geological record in the Roer Valley Graben (Houtgast \& Van Balen, 2000). Several earthquakes were recorded during that 50 year period within a radius of several kilometers from the leveling profile, including a moderate earthquake of 5.0 (the Uden earthquake, Houtgast, 1991). A further indication of postseismic relaxation creep of this type is provided by a small farmhouse, build in the late 1940's on the Peel Boundary Fault $10 \mathrm{~km}$ east of Roermond. The fault is crossing the house, causing an offset of $20 \mathrm{~cm}$ in the rooftop (TNO-NITG, 2001).

An important implication of postseismic displacement is that there is no relation between (total) dis- placement observed or inferred at the surface and the magnitude of the corresponding earthquake at depth. Thus, these postseismic displacements cannot be used to infer the magnitudes of paleo-earthquakes. In contrast, liquefaction features are related to earthquakes (Obermeier, 1996). Thus, if earthquake fluidizations can be discriminated from other liquefactions, like fluidizations originating in periglacial environments, the presence of fluidization structures can be used to infer earthquakes and may put lower limits on their magnitudes (Obermeier, 1996). However, only if liquefaction structures can be clearly correlated to fault displacements, can this be used as evidence for a direct relationship between an earthquake and the inferred displacement.

\section{Previous paleo-seismological research in the Roer Valley Graben}

The main faults of the Lower Rhine Embayment have been investigated by several trench studies (e.g. Camelbeeck \& Meghraoui, 1998; Meghraoui et al., 2000; Vanneste et al., 1999; Vanneste \& Verbeeck, 2001; Lehmann et al., 2001; Van den Berg et al., 2002). Based on an extensive research program (Commission of the European Communities (ed), 2000), Vanneste et al. (1999) report at least six surface rupturing events during the Late Pleistocene evidenced in one trench, and Camelbeeck et al. (2000; 2001) inferred three events based on a compilation of the results of four trenches. There is not much support presented in these publications for a coseismic interpretation of the observed fault displacements. Obermeier (1996) lists seven criteria to determine a coseismic origin of liquefactions. These criteria are cited by Vanneste et al. (1999), but they state that the evidence for soft-sediment deformation in the trenches using these criteria is rather limited. They do mention additional indirect arguments such as their close association of different deformational features and the vicinity of the deformations to a known active fault.

In a trench study along the Rurrand Fault, the extension of the Peel Boundary Fault into Germany, Vanneste \& Verbeeck (2001) show that the faulting history of the Rurrand Fault at this location is clearly episodic, since growth faulting that could be indicative for continuous, postseismic creep has not been observed. However, the stratigraphic control is insufficient to constrain the timing and to find evidence for the coseismic nature of each inferred displacement. Vanneste \& Verbeeck (2001) furthermore point to the position of two solifluction lobes of remarkably young age ( $<400$ cal. BC). Their position, controlled by 
faults, suggests that the extensive solifluction is triggered by two surface rupturing events. However, the position of a solifluction lobe adjacent to a fault alone does not directly imply that the solifluction event is triggered by surface rupturing earthquakes. A fault, by whatever mode of motion, postseismic or coseismic, can create a scarp, and a slope of only $2 \%$ is required to trigger a solifluction event (French, 1974), without the need for an earthquake.

The presence of coseismic liquefaction structures is no proof for coseismic slip along faults. During the Roermond earthquake of 1992, liquefaction occurred (Davenport et al., 1994), but no fault slip at the surface was reported. A stratigraphical relationship between the two features, fault displacement and liquefaction structures present in a trench, has to be proven. Nevertheless, we admit that this is very difficult indeed, because liquefactions due to seismic shaking could occur at a distance of tens or even hundreds of kilometers away from the epicenter (McCalpin, 1996). Other publications concerning trenches in the Roer Valley Graben (e.g. Meghraoui et al., 2000; Frechen et al., 2001; Van den Berg et al., 2002) do not discuss the topic of a postseismic versus coseismic interpretation of fault offsets in trenches. We conclude that to this date there is not sufficient evidence for coseismic slip along the excavated faults of the Roer Valley Graben.

\section{Paleo-seismological implications of this research}

In this research the main fault of the Geleen Fault Zone (fault F1 in Fig. 9) was reset by a landslide, which leveled the surface directly above the fault. Above this level all units have been dated by OSL to around $15 \mathrm{ka} \mathrm{B.P.} \mathrm{The} \mathrm{analysis} \mathrm{of} \mathrm{the} \mathrm{average} \mathrm{fault}$ displacement rate in the Geleen Fault trench revealed that this period had a significant larger average displacement rate (at least $2-3$ times) compared to the period before and after $15 \mathrm{ka}$ B.P. (Table 3). The liquefaction features affecting unit $\mathrm{E} 1$, indicate a significant earthquake. After the moderate earthquake of Roermond (April, 1992) several liquefaction features were reported (Davenport et al., 1994). Therefore, an earthquake of magnitude Mw 5.4 is sufficient to create these features in the geological setting of the Lower Rhine Embayment. The liquefaction structures in the trench could not be linked stratigraphically to an offset along the main fault. Instead, a displacement of $20 \mathrm{~cm}$ is found in the deposits overlying and truncating the liquefaction structures (unit E2). This leaves two possibilities, in the first one the earthquake (evidenced by the liquefaction features) occurred and the inferred increase in fault displacement is the delayed response to that earthquake, i.e. both features belong to the same event. The other possibility is that the liquefactions are the result of an earthquake, possibly with its epicenter located far away, and that the inferred increase in fault displacement is the result of another earthquake, i.e. the two features are the results of separate events. This latter earthquake could not create liquefaction at the location of the trench, because the liquefaction potential was exhausted at this location. We know that the time window for both events (liquefaction and the increase in fault activity) is $2.7 \mathrm{ka}$ (see above). To cause liquefaction or a surface rupture, an earthquake with a magnitude of at least 5.0 to 5.5 on the Richter scale is needed ( $\mathrm{Mc}$ Calpin, 1996). The reoccurrence time in the Roer Valley Graben (based on instrumental and historical earthquake records, Camelbeeck et al., 1996) for earthquakes with a magnitude larger than 5.0 is between 1000 and 2000 years, and for an earthquake with a magnitude of 5.5 approximately 3000 to 5000 years. Given the present-day frequency-magnitude distribution the second model (two separate events) cannot be rejected. However, the time window of 2.7 $\mathrm{ka}$ is a maximum (inferred from the maximum time to deposit unit E) and the time interval between the liquefaction and the increase in fault activity (both situated in the lower to middle part of unit E) is probably considerably smaller, leaving the second model not very likely. Furthermore, present-day observations, like the large vertical ground movements in Uden (Fig. 13) or the liquefactions caused by the Roermond earthquake, not accompanied by a surface rupture, do support the first model. Thus, we support the first model whereby the liquefaction event and the fault displacement are separated in time, but belong to the same event.

We conclude that around $15 \mathrm{ka} \mathrm{B.P.} \mathrm{at} \mathrm{least} \mathrm{one}$ earthquake occurred, which was large enough to cause liquefaction. Subsequently, the main fault of the Geleen Fault Zone moved at least two to three times faster than the long-term average displacement rate. These high rates are closer to the rates determined by geodetic measurements reported by Groenewoud et al. (1991) than the long-term average rates. The period of rapid displacement was succeeded by a period characterized by a displacement rate comparable to the long-term average. We could not establish how long the period of higher displacement rates has lasted. OSL dating gives a maximum duration of 2700 years. A minimum duration is impossible to establish, but the deposition of the finely laminated sands of unit E2 may have been rapid. Geodetic measurements carried out over the Peel Boundary Fault Zone, which experienced a moderate earthquake in 


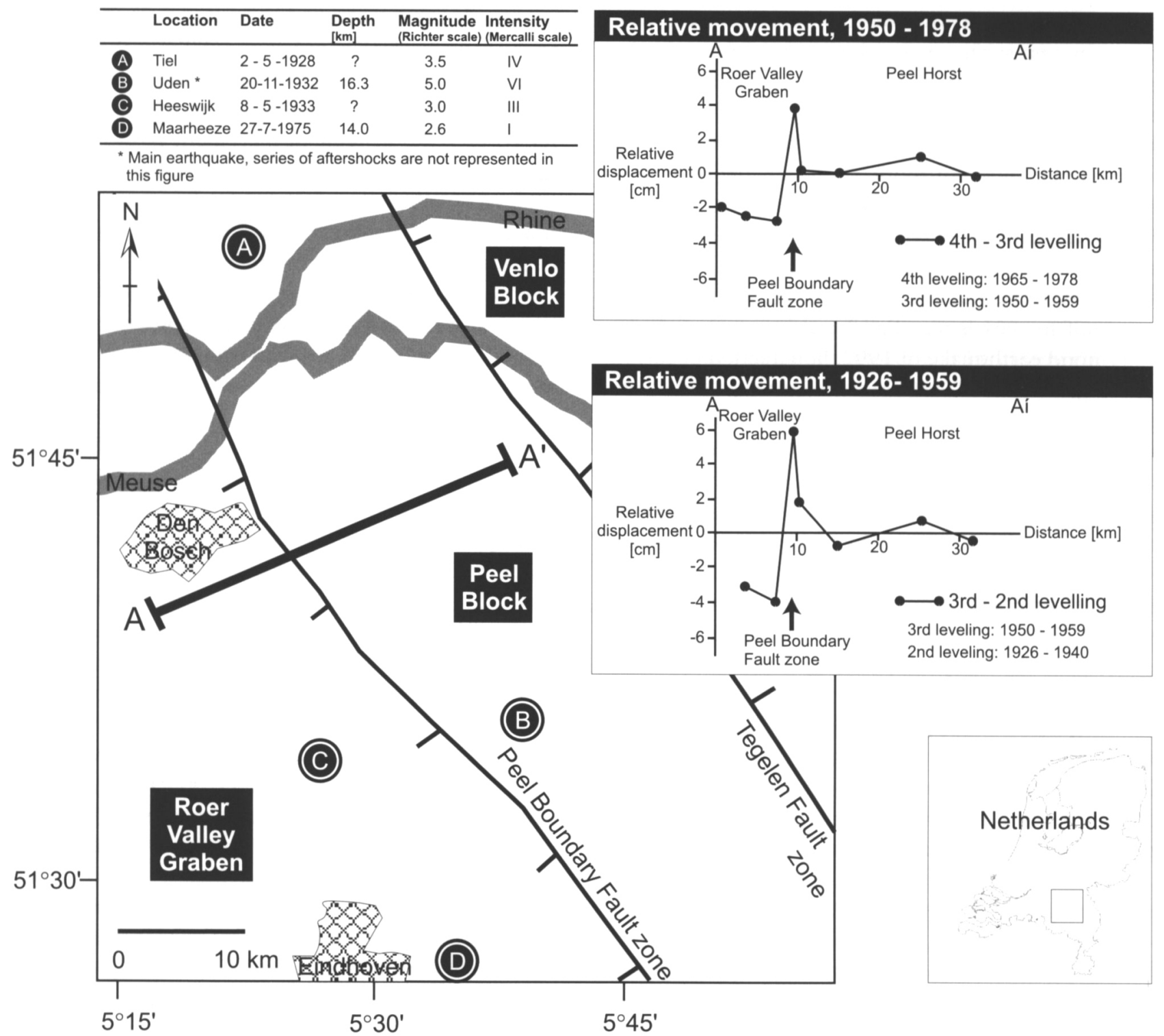

Fig. 13. Location of geodetic profile and the inferred relative vertical movements across the Peel Boundary Fault from 1926 to 1978 (after Groenewoud et al., 1991). The location (epicenter) of earthquakes $(M>2.5)$ during the same period is shown (after Houtgast, 1991).

1932, suggests that a period of higher postseismic slip rates could last at least 50 years (Groenewoud et al., 1991).

The separation in time between the earthquake event (of $15 \mathrm{ka} \mathrm{B.P.)} \mathrm{and} \mathrm{the} \mathrm{consequent} \mathrm{displace-}$ ment rate increase at the Geleen Fault is in accordance with the first model outlined above. The period of increased displacement rate is the stress relaxation response to the earthquake (at $10-20 \mathrm{~km}$ depth), which induced fluidization. Therefore, we question the reconstructed magnitudes of paleo-earthquakes derived only from vertical displacements at outcrops for the geological setting of the Roer Valley Graben. However, the ages found for these displacement events, whether coseismic or postseismic, do refer to periods of increased fault activity, possibly preceded by (a) moderate to large earthquake(s).

\section{Conclusions}

In this study the Geleen Fault, part of the Feldbiss Fault Zone in the Sittard area, has been excavated. The results show that the Geleen Fault experienced a period of increased fault activity $\left(0.13 \mathrm{~mm} \mathrm{a}^{-1}\right)$ at approximately $15 \mathrm{ka}$ B.P. During this period the average fault displacement rate was at least $2-3$ times larger than the long-term average $\left(0.02-0.04 \mathrm{~mm} \mathrm{a}^{-1}\right)$ inferred from the geology of the trench and from regional studies. During this period at least one earthquake occurred large enough to cause liquefaction. Fault displacement along the main fault (fault F1, Fig. 9) could not be stratigraphically linked to this event. To the contrary, the liquefaction event (earthquake) is separated in time from the main offset along the main fault. This suggests that in the geological context of 
the Roer Valley Graben the response at the surface to a displacement at depth is delayed. This implies that there is no direct relationship between a displacement at depth and the vertical fault displacement at the surface. Therefore, we suggest that the estimations of magnitudes of paleo-earthquakes derived from vertical displacements at an outcrop of a fault are tentative, in the geological context of the RoerValley Graben.

\section{Acknowledgements}

The research presented in this paper is a contribution to the NEESDI (Netherlands Environmental Earth System Initiative) programme, funded by the Netherlands Organization for Scientific Research (NWO). We thank Dick Van der Wateren, Sierd Cloetingh, Victor Bense, Elmer van den Berg, Jop Brijker, Laurens Bouwer, Gert Brand, Thomas Hoek, Remke van Dam and Michel Groen for their cooperation and assistance in the field, and Patrick Bogaart and Jeroen Kenter for the use of their photographs. We are gratefull to Mark Bateman for the OSL dating and to Jacob Wallinga for his expert opinion. We thank $\mathrm{K}$. Lehmann and $\mathrm{H}$. Cetin for their detailed and valuable comments on the manuscript.

\section{References}

Ahorner, L., 1962. Untersuchungen zur Quartären Bruchtektonik der Niederrheinischen Bucht. Eiszeitalter und Gegenwart 13: 24-105.

Camelbeeck, T., van Eck, T., Pelzing, R., Ahorner, L., Loohuis, J., Haak, H.W., Hoang-Trong, P. \& Hollnack, D., 1994. The 1992 Roermond earthquake, the Netherlands, and its aftershocks. Geologie en Mijnbouw 73: 181-197.

Camelbeeck, T. \& Meghraoui, M., 1996. Large earthquakes in Northern Europe, more likely than once thought. Eos, Transactions American Geophysical Union 77: 405-409.

Camelbeeck, T. \& Meghraoui, M., 1998. Geological and geophysical evidence for large palaeo-earthquakes with surface faulting in the Roer Graben (Northwest Europe). Geophysical Journal International 132: 347-362.

Camelbeeck, T., Alexandre, P., Vanneste, K. \& Meghraoui, M., 2000. Long-term seismicity in regions of present day low seismic activity: the example of western Europe. Soil Dynamics and Earthquake Engineering 20: 405-414.

Camelbeeck, T., Martin, H., Vanneste, K., Verbeeck, K. \& Meghraoui, M., 2001. Morphometric analysis of active normal faulting in slow-deformation areas; examples of the Lower Rhine Embayment. Netherlands Journal of Geosciences / Geologie en Mijnbouw 80: 95-107.

Commission of the European Communities (ed) 2000. Evaluation of the potential for large earthquakes in regions of present day low seismic activity in Europe. Final report no. ENV4-CT970578. Directorate-General XII for Science, research and development (Brussels): $135 \mathrm{pp}$.

Cowan, D.S., 1999. Do faults preserve a record of seismic slip? A field geologist's opinion. Journal of Structural Geology 21: 995 -1001 .
Davenport, C.A., Lap, J.M.J., Maurenbrecher, P.M. \& Price, D.G., 1994. Liquefaction potential and dewatering injection features at Herkenbosch: Field investigations of the effects of the Roermond earthquake, the Netherlands. Geologie en Mijnbouw 73: 365374.

Felder, W.M., Bosch, P.W. \& Bisschops, J.H., 1989. Geologische kaart van Zuid-Limburg en omgeving, schaal 1:50.000. Afzettingen van de Maas. Rijks Geologische Dienst, Haarlem.

Frechen, M., Vanneste, K., Verbeeck, K., Paulissen, E. \& Camelbeeck, T., 2001. The deposition history of the coversands along the Bree Fault escarpment. Netherlands Journal of Geosciences / Geologie en Mijnbouw 80: 171-185.

French, H.M., 1974. Mass-wasting at Sachs Harbour Banks Island, N.W.T., Canada. Artic and Alpine Research 6: 71-78.

Geluk, M.C., Duin, E.J.Th., Dusar, M., Rijkers, R.H.B., Van den Berg, M.W. \& Van Rooijen, P., 1994. Stratigraphy and tectonics of the Roer Valley Graben. Geologie en Mijnbouw 73: 129-141.

Groenewoud, W., Lorenz, G.K., Brouwer, F.J.J. \& Molendijk, R.E., 1991. Geodetic determination of recent land subsidence in the Netherlands. In: Land subsidence (Proceedings of the 4th international symposium on land subsidence, may 1991). IAHS Publ. No 200.

Houtgast, G., 1991. Catalogus van aardbevingen in Nederland. KNMI publicatie 179, De Bilt, Netherlands.

Houtgast, R.F. \& Van Balen, R.T., 2000. Neotectonics of the Roer Valley Rift System, the Netherlands. Global and Planetary Change 27: 131-146.

Houtgast, R.F., Van Balen, R.T., Bouwer, L.M., Brand, G.B.M. \& Brijker, J.M., 2002. Late Quaternary activity of the Feldbiss Fault Zone, Roer Valley Rift System, the Netherlands, based on displaced fluvial terrace fragments. Tectonophysics 352: 295-315.

Huxtable, J. \& Aitken, J., 1985. Thermoluminescence dating results for the Palaeolithic site Maastricht-Belvedère. Mededelingen Rijks Geologische Dienst 39-1: 41-44.

Huijzer, A.S., 1993. Cryogenic microfabrics and macrostructures: interrelations, processes and paleoclimatic significance. Thesis Vrije Universiteit Amsterdam. Copyprint Enschede: 245 pp.

Lehmann, K., Klostermann, J. \& Pelzing, R., 2001. Paleoseismological investigations at the Rurrand Fault, Lower Rhine Embayment. Netherlands Journal of Geosciences / Geologie en Mijnbouw 80: 139-154.

McCalphin, J.P., 1996. Paleoseismology. Academic Press (San Diego): $588 \mathrm{pp}$.

Meghraoui, M., Camelbeeck, T., Vanneste, K., Brondeel, M. \& Jongmans, D., 2000. Active faulting and paleoseismology along the Bree fault zone, Lower Rhine graben (Belgium). Journal of Geophysical Research 105: 13809-13841.

Mücher, H.J., 1986. Aspects of Loess and loess-derived slope deposits: an experimental and micromorphological approach. Fysisch Geografisch en Bodemkundig Laboratorium, Universiteit van Amsterdam: $267 \mathrm{pp}$.

Murray, A.S. \& Wintle, A.G., 2000. Luminescence dating of quartz using an improved single-aliquot regenerative-dose protocol. Quaternary Research 27: 1-29.

Obermeier, S.F., 1996. Use of liquefaction-induced features for paleoseismic analysis - An overview of how seismic liquefaction features can be distinguished from other features and how their regional distribution and properties of source sediment can be used to infer the location and strength of Holocene paleo-earthquakes. Engineering Geology 44: 1-76.

Paulissen, E., Vandenberghe, J. \& Gullentops, F., 1985. The Feldbiss fault in the Maas valley bottom (Limburg, Belgium). Geologie en Mijnbouw 64: 79-87.

Plenefisch, T. \& Bonjer, K.-P., 1997. The stress field in the Rhine Graben area inferred from earthquake focal mechanisms and es- 
timation of frictional parameters. Tectonophysics 275: 71-97.

TNO-NITG, 2001. Toelichting bij de kaartbladen XIII en XIV Breda-Valkenswaard en Oss-Roermond. Netherlands Institute for Applied Geosciences TNO, Utrecht.

Vandenberghe, J., 1983. Some periglacial phenomena and their stratigraphical position in Weichselian deposits in the Netherlands. Polarforschung 53 (2): 97-107.

Van den Berg, M.W., 1989. Geomorfologische kaart van Nederland 1:50.000 kaartblad 59 Genk, 60 Sittard, 61 Maastricht, 62 Heerlen, met toelichting ( $32 p$ ) en de kaart Maasterrassen en hellingklassen. Staring Centrum, Wageningen en Rijks Geologische Dienst, Haarlem.

Van den Berg, M.W., Vanneste, K., Dost, B., Lokhorst, A., van Eijk, M. \& Verbeeck, K., 2002. Paleoseismological investigations along the Peel Boundary Fault: geological setting, site selection and trenching results. Netherlands Journal of Geosciences / Geologie en Mijnbouw 81: 39-60.
Van Kolfschoten, T., Roebroeks, W. \& Vandenberghe, J., 1993. The Middle and Late Pleistocene sequence at Maastricht-Belvédère: the type locality of the Belvédère Interglacial. Mededelingen Rijks Geologische Dienst N.S. 47: 81-91.

Vanneste, K., Meghraoui, M. \& Camelbeeck, T., 1999. Late Quaternary earthquake-related soft-sediment deformation along the Belgian portion of the Feldbiss Fault, Lower Rhine Graben system. Tectonophysics 309: 57-79.

Vanneste, K. \& Verbeeck, K., 2001. Paleoseismological analysis of the Rurrand fault near Jülich, Roer Valley Graben, Germany: Coseismic or aseismic faulting history? Netherlands Journal of Geosciences / Geologie en Mijnbouw 80: 155-169.

Zijerveld, L., Stephenson, R., Cloetingh, S., Duin, E. \& Van den Berg, M.W., 1992. Subsidence analysis and modelling of the Roer Valley Graben (SE Netherlands). Tectonophysics 208: 159171. 